\title{
Erzurum İli Doğa Olayları Profili ve Deprem Tehlikesi
}

\author{
Nazlı Ceyla ANADOLU KILIÇ1
}

\begin{abstract}
Özet
Dünyanın oluşumundan günümüze kadar geçen süre içerisinde her coğrafi bölge kendi iç dinamiklerine yani jeofiziksel, meteorolojik, hidrolojik ve iklimsel özelliklerine bağlı olarak birçok doğa olayına ev sahipliği yapmaktadır. Ancak her doğa olayı afet potansiyeli taşımamakla birlikte küresel bir sorun haline gelen iklim değişikliğinin yanı sıra bilinçsiz kentleşme, plansız sanayileșme, kontrol edilemeyen nüfus artışı ve göç gibi insani faktörlere bağlı olarak sıklıkla afete dönüşebilmektedir. Özellikle son yıllarda doğa olaylarının afete dönüşme oranının artmasıyla yaşanan maddi kayıpların ve manevi zararların ülke ekonomileri üzerinde yarattığı olumsuz etki düşünüldügünde her bir coğrafi bölge için afet potansiyelinin belirlenmesi gerekliliği önem kazanmaktadır. Bunun için her coğrafi bölgenin doğa olayı-doğal afet potansiyeli kendi özellikleri dâhilinde incelenmeli ve afet tanımlamaları, modellemeleri ve senaryoları o bölgeye özel olarak oluşturulmalıdır. Bu çalışmada ulusal-uluslararası veri tabanları ve ulusal basın incelenerek Erzurum ili için 1900-2019 yılları arasında meydana gelen belirli doğa olaylarını kapsayan güncel bir veri envanteri oluşturulmuştur. Doğa olaylarının oluşum nedenleri, birbirleri ile ilişkileri ve sonuçları tespit edilmiş; bu doğa olaylarının afet potansiyeli taşıyıp taşımadıkları belirlenmiştir. Sonuç olarak, çalışma alanı için çı̆̆, deprem ve sel olaylarının afet potansiyeli taşıdığı tespit edilmiştir. Çalıșma alanının aktif tektonik yapısı ve deprem ile diğer doğa olayları arasındaki ilişki nedeniyle deprem tehlike analizi ile yakın gelecek için deprem tehlike oranı ve tekrarlanma periyodları belirlenmiştir. Elde edilen sonuçlara göre 1 yılda $\mathrm{Mw}=5.0$ büyüklügü̈ndeki bir depremin olma ihtimali Gumbel Modeline göre \%26 olarak belirlenirken, Poisson Modeline göre $\% 30$ 'dur.
\end{abstract}

Anahtar Kelimeler: Afet, Doğa Olayı, Deprem, Tehlike, Risk, Erzurum İli

\section{Erzurum Province Natural Events Profile and Earthquake Hazard}

\begin{abstract}
Each geographical region hosted many natural events depending on their inner dynamics, that is; geophysical, meteorological, hydrological and climatological properties, starting from the time of the World's formation. Although each natural event does not have a potential to be a natural disaster, they can transform into natural disasters quite often depending on human factors like unconscious urbanization, unplanned industrialization, non-controllable increase of population and migration together with climate change which has become a global problem. Particularly in recent years with the increasing rate of transformation of natural events into natural disasters,
\end{abstract}

1Dr. Öğr. Gör., Bilim Teknoloji Uygulama ve Araştırma Merkezi, Nevşehir Hacı Bektaş Veli Üniversitesi, Nevşehir İlgili yazar e-posta / Corresponding author e-mail: nazlianadolu@nevsehir.edu.tr ORCID No: 0000-0002-8769-3510 
when the negative effect of resulting financial loss and intangible damage on national economies is taken into account, the necessity of determining the potential of natural disasters for each region gains importance. Therefore, natural event-natural disaster potential of each region should be investigated within its own properties and disaster descriptions, modelings and scenarios should be created in a region-specific manner. In this study, an up-to-date data inventory was created consisting of significant natural events which took place between 1900-2019 in Erzurum province, utilizing national-international databases and national press. Causes of natural events, their relationships and results were determined and it was found whether these natural events have potential to be natural disasters. As a result, it was found that natural events of avalanche, earthquake and flood were found to have potential of disaster within the frame of study area. As a consequence of active tectonic structure of the study area and the relationship of earthquake and other natural events, by using earthquake hazard analysis, earthquake hazard ratio and recurrence periods were determined for the near future. According to results, the possibility of an earthquake with $\mathrm{Mw}=5.0$ magnitude is $26 \%$ in a year according to Gumbel Model and $30 \%$ according to Poisson Model.

Keywords: Disaster, Natural Event, Earthquake, Hazard, Risk, Erzurum Province

\section{GİRIS}

Bilinen insanlık ve dünya tarihi boyunca insanoğlunun yüzleştiği ve tam olarak çözüme kavuşturamadığı ortak problemlerin başında doğal afetler karşısında yaşadığı çaresizlik gelmektedir. Bir anda oluşan ve önlenemeyen doğa olaylarının afete dönüşmesi tarihsel dönemlerde medeniyetlerin dini inançları bağlamında ele alınırken modern dünyada doğa olaylarının afete dönüşmeden engellenebilir bir olgu olduğu bilinen bir gerçektir. Buna rağmen, meydana gelen birçok doğa olayı afete dönüşmekte ve bu durum karşısında aciz kalan insanoğlu toplumsal, sosyal, çevresel ve kültürel kayıplar vermeye devam etmektedir.

Evrensel bir sorun olarak ele alınması gereken doğa olayları ve doğal afet ile ilgili ulusal ve uluslararası literatürde birbirinden farklı kavramlar ve tanımlamalar bulunmaktadır. Bu durum zaman zaman kavram karmaşasına yol açmakta ve dolayısıyla konu ile ilgili yapılan çalışmalarda standart bir dilin oluşmasına engel olmaktadır. Yapılan çalışmalar incelendiğinde özellikle "tehlike" ve "afet" ile "tehlike" ve "risk" kavramlarının birbirlerinin yerine sıklıkla kullanılan kavramlar olduğu görülmektedir. Birbirlerinden oldukça farklı anlamlara sahip olan bu kavramların hem günlük hayatta hem de bilim dünyasında sıklıkla birbirlerinin eș anlamlıları olarak kullanıyor olması nedeniyle, yapılan bu çalışmada öncelikle temel kavramlar üzerinde durulmuştur.

Tehlike; meydana geldiği zaman diliminde ve/veya coğrafyada fiziksel, ekonomik, sosyal kayıplara yol açması mümkün doğa, teknoloji veya insan kaynaklı olayları ifade etmek için kullanılan bir kavram iken afet bu olayın kendisi değil, yol açtığı kayıp yani doğurduğu olumsuz sonuçtur. En genel tanımı ile afet insanlar için fiziksel, ekonomik ve sosyal kayıplar doğuran, normal yaşamı ve insan faaliyetlerini durdurarak veya kesintiye uğratarak toplulukları olumsuz etkileyen ve etkilenen topluluğun kendi olanak ve kaynaklarını kullanarak üstesinden gelemeyeceği, doğa, teknoloji veya insan kaynaklı olayların sonuçlarına verilen genel bir isimdir. Tehlike ve afet tanımlarından da anlaşılacağı üzere deprem, sel, volkan püskürmeleri gibi doğa kaynaklı oluşumlar tek başlarına değerlendirildiklerinde afet olarak değil doğal tehlike olarak kabul edilmelidirler. Aksi takdirde ıssız bir adada meydana gelen herhangi bir maddi ve manevi kayıp yaratma potansiyeli olmayan bir deprem ile nüfusun, yapılaşmanın ve sanayinin yoğun olduğu bir coğrafi bölgede meydana gelen aynı büyüklükteki deprem aynı kategoride değerlendirilmiş olacaktır. Sonuç olarak tehlike ve afet tanımlarından yola çıkarak iki kavram arasındaki ilişki Afet 
= Tehlike x Hasar Görebilirlik şeklinde tanımlanır. Afet ile tehlike arasındaki ilişkinin tanımlanmasında önemli rol oynayan ve çok yönlü bir kavram olan hasar görebilirlik ise toplum, yapı, sosyal hizmet, kültürel miras, çevre düzeni gibi unsurların tehlike meydana geldiği zaman yaşaması muhtemel fiziksel, sosyal, ekonomik ve çevresel kayıp ve zararların ölçüdür. Yani tehlike olarak tanımlanan olayların afet kategorisinde değerlendirilebilmeleri için hasar görebilirlik unsuruna sahip olmaları gerekmektedir.

Hem birey hem de toplum için tehdit oluşturan risk ise bir olayın belirli koşul ve ortamlarda doğurabileceği fiziksel, sosyal ve ekonomik vb. kaybın gerçekleşme olasılığı olarak tanımlanır ve tehlike arasındaki ilişki de Risk =Tehlike x Hasar Görebilirlik x Etkilenebilecek Unsurlar şeklinde ifade edilir. Sonuç olarak belirli bir zaman dilimi ve/veya coğrafi bölge için risk çalışması yapılabilmesi için, öncelikle bir olayın yani tehlikenin var olması ve tanımlanması gerekmektedir. İkinci aşamada ise, yapılan bu tanımlama sonucunda etkilenebilecek unsurların varlığı ile bu unsurların tehlikeden etkilenme oranları yani hasar görebilirliklerinin tahmin edilmesi gerekmektedir.

Belirli bir zaman ve/veya coğrafi bölgede yapılacak doğa olayları kaynaklı farklı disiplinlere ait çalışmalarda tehlike, afet ve risk kavramlarının ve aralarındaki ilişkilerinin doğru bir şekilde ifade edilmesinden sonra yapılması gereken ilk işlem afetle mücadelede öncelik verilmesi gereken alt bölgelerin ve unsurların tespit edilmesi olmalıdır. Herhangi bir doğa olayının herhangi bir coğrafi bölge için afet oluşturma potansiyeline sahip olmayabileceği ya da hasar görebilirlik ve etkilenecek unsurların durumuna bağlı olarak daha az öneme sahip olabileceği göz önünde bulundurulursa yerel, ulusal ve uluslararası bazda yapılacak belirli bir standardizasyona sahip afet profili belirleme çalışmalarının önemi ortaya çıkmaktadır. Yapılacak kapsamlı afet profili çalışmaları neticesinde elde edilecek sonuçlar ışığında alt bölgeleri önem sıralamasına göre daha detaylı çalışmalar ile incelemek ve meydana gelen tehlike afete dönüşmeden afet sonrası yapılacak işlemleri ve alınacak önlemleri planlayarak afet zararlarını azaltmak ya da önlemek için alt bölgelerin tarihi ve coğrafi özellikleri, demografik yapısı, geçim modelleri ile uyumlu özel afet senaryoları oluşturarak afet ile mücadelede daha sağlıklı yol alınması mümkün olabilmektedir.

Geçmişi M.Ö. 4000'lere kadar uzanan Erzurum ili ve çevresine ait arkeolojik kalıntılar çalışma alanının tarih öncesi dönemde de tarih sonrası dönemde olduğu gibi önemli medeniyetlere ev sahipliği yaptığını göstermektedir. Sahip olduğu tarihi öneminin yanı sıra bilinen jeolojik, jeofiziksel, jeomorfolojik ve meteorolojik özellikleri nedeniyle Erzurum ili ve çevresinde farklı disiplinlere ait birbirinden farklı doğa olayı ve afet çalışmaları yapılmıştır. Ancak yapılan akademik çalışmalar incelendiğinde Erzurum ili ve çevresinde meydana gelen doğa olaylarının ya Türkiye'nin tamamı için yapılan çalışmalar kapsamında rakamsal/istatistiksel olarak incelendiği ya da meydana gelen tek bir doğa olayının yarattığı bölgesel etkiler ve sonuçların ortaya konduğu görülmüştür (Girgin, 1996; Öztürk, 2002; Gökçe vd., 2008; Kopar, 2010; Özşahin, 2013; Huvaj vd., 2014; Şahin vd., 2016; Öztürk ve Çimentepe, 2016; Yönlü vd., 2016; Öztürk, 2017, 2018). Yapılan bu akademik çalışmalar dışında Erzurum Çevre ve Şehircilik İl Müdürlüğü ve Erzurum Valiliği İl Afet ve Acil Durum Müdürlügü tarafından hazırlanan farklı yıllara ait raporlar da bulunmaktadır. Ancak, güncel yaşanan doğa olayları sonrasında görülen maddi ve manevi kayıplar geçmişte yaşanan ve tespit edilen sorunlara hala çözüm üretilemediğini ve şehirleşme çalışmalarında bu olguların göz önünde bulundurulmadığını düşündürmektedir. Bu bulgular ışığında Erzurum ili ve çevresi için kapsamlı bir doğa olayı ve afet çalışmasının bulunmamasının önemli bir eksiklik olduğunu söylemek mümkündür.

Yapılan bu çalışma ile Türkiye'nin en kalabalık yirmi dokuzuncu ili, Doğu Anadolu Bölgesi'nin ise en büyük üçüncü ili olan Erzurum ili için tespit edilen bu eksikliğin giderilmesi ve elde edilen sonuçlar aracılığı ile de kapsamlı bir doğa olayı-afet potansiyeli ilişkisi irdelemesi yapılması 
amaçlanmıştır. Bu amaçla, öncelikle 1900-2019 yılları arasında meydana gelen doğa olaylarının zamansal ve mekânsal dağılımı incelenerek güncel, kapsamlı, güvenilir bir veri envanteri oluşturulmuştur. Böylelikle çalışma alanı içerisinde fiziksel, sosyal, ekonomik ve çevresel hasar görebilirlik yaratan doğa olaylarının oluşum mekanizmaları, oluşum yerleri ve birbirleri ile ilişkileri belirlenmiş olup afet oluşturan ve oluşturma potansiyeli yüksek olan doğa olayları ve afeti yaşamış ve ileride de yaşama potansiyeli olan ilçeler tespit edilmiştir. Ayrıca yapılan deprem tehlike analizinde iki farklı dağılım modeli kullanılarak çalışma alanında etki değeri büyük olan deprem olayının güncel durumu ortaya konulmuştur.

\section{MATERYAL VE METOT}

Yaklaşık olarak $25.000 \mathrm{~km}^{2}$ yüz ölçümüne sahip olan Erzurum iline ait toprakların büyük bir çoğunluğu, ortalama \%70 kadarı, Doğu Anadolu Bölgesi sınırları içerisinde yer alırken; \%30 kadarı ise Karadeniz Bölgesi sınırları içerisinde yer almaktadır. Yirmi ilçesi bulunan Erzurum ilinde ilçelerin deniz seviyesinden yüksekliği $1140 \mathrm{~m}$ ile $2360 \mathrm{~m}$ arasında değiş̧irken; il merkezi sahip olduğu 1900 m'lik rakım değeri ile Türkiye genelinde en yüksek rakıma sahip il merkezlerinden biri olarak ön plana çıkmaktadır. Yüksek rakım değerlerine ilaveten çalışma alanının yaklaşık olarak \%64'ünün dağlık alanlardan yani yüksek arazilerden oluşması iklim ve bitki örtüsü üzerinde oldukça etkili sonuçlar yaratmaktadır. Bu durumun bir doğal sonucu olarak çalışma alanı içerisinde; Türkiye sınırları içerisinde sıklıkla görülmeyen sert karasal iklim yaşanmakta ve hâkim bitki örtüsü olarak step formasyonu görülmektedir. Çalışma alanının kuzey kesiminde yüksekliğin 1000-1500 m gerilediği vadi içlerinde iklim sert özelliğini kaybetse de genel olarak kışlar uzun ve sert, yazlar kısa ve sıcak geçmektedir. Ormanlık alanların fazla yaygın olmadığı çalışma alanı içerisinde Alpin çayırları ve Tayga ormanları görülmekte, 1900-2000 metrelerde başlayan orman örtüsü 2400 metrelerde son bulmaktadır. Yapılan çalışmalar sonucunda; gözlenen orman örtüsü dışında dağlardaki ve dağ yamaçlarındaki orman kalıntıları geçmiş dönemlerde çalışma alanının zengin bir bitki örtüsüne sahip olabileceğini ve var olan bu bitki örtüsünün başta insani faktörler olmak üzere çeşitli faktörlere bağlı olarak yok edilmiş olabileceğine dair bir ipucu olarak değerlendirilmektedir (Kafalı, 2017).

Depremsellik açısından ise Doğu Anadolu Sıkışma Bölgesi'nde yer alan çalışma alanı Kuzey Anadolu Fay Zonu ve Doğu Anadolu Fay Zonu'nun etkisi altında bulunmaktadır. Oldukça aktif tektonik yüzeylerden oluşan ve önemli kırık sistemlerine sahip olan çalışma alanı içerisinde Aşkale Fay Zonu, Başköy-Kandilli Fay Zonu, Palandöken Fay Zonu ve Erzurum-Dumlu Fay Zonu dört temel unsur olarak ön plana çıkmaktadır. Çalışma alanı içerisinde hem tarihsel dönem de hem de aletsel dönemde büyük ve yıkıcı depremler sıklıkla yaşanmış ve yaşanmaya da devam edilecektir.

Sonuç olarak; çalışma alanının aktif tektonik yapısı, meteorolojik durumu özellikle de yılın büyük bir bölümünde etkili bir şekilde hissedilen meteorolojik özellikleri, klimatolojik unsurları göz önüne alındığında birçok doğa olayının yaşanması için elverişli olduğu görülmektedir. Bu nedenle çalışma alanı içerisinde yerbilimi verileri dikkate alınarak yapılacak doğa olayı analizleri ile çevresel faktörlerin etkilerinin incelenmesi doğal afet ve tehlike çalışmaları için hayati önem taşımaktadır.

$\mathrm{Bu}$ amaç doğrultusunda yapılan çalışmada; ilk olarak Afetler Epidemiyolojisi Araştırma Merkezi (CRED) tarafından geliştirilen EM-DAT (Emergency Events Database- Acil Durum Veri Tabanı) veri tabanı sınıflaması esas alınarak incelenmesi gereken doğa olayları belirlenmiştir (URL 1). Ve çalışma alanı için çı̆̆, deprem, heyelan, kaya düşmesi ve sel olaylarının incelenmesinin gerekli olduğu tespit edilmiştir. Bu seçimin en temel nedeni; çalışma alanı içerisinde deprem, kuru kütle haraketleri gibi jeofiziksel kökenli doğa olayları ile hidrolojik kökenli doğa olayları arasındaki ilişkinin varlığının ve boyutunun ortaya konulmak istenmesinden kaynaklanmaktadır. 
Çalışma kapsamında incelenecek doğa olaylarının belirlenmesinden sonra Erzurum iline ait ve 1900-2019 yıllarını kapsayan güncel bir doğa olayı envanteri oluşturmak için Birleşmiş Milletler tarafından geliştirilen DesInventar, Afetler Epidemiyolojisi Araştırma Merkezi (CRED) tarafından geliştirilen EM-DAT, Afet ve Acil Durum Yönetimi Başkanlığı (AFAD) tarafından geliștirilen Türkiye Afet Bilgi Bankası (TABB) ve İstanbul Büyükșehir Belediyesi Afet Koordinasyon Merkezi tarafından geliştirilen AKOM Afet Bilgi Sistemi (AKOMAS) veri tabanlarının çalışmada kullanılmasına karar verilmiştir. Ulusal ve uluslararası veri tabanları haricinde yapılan çalışmada farklı kurum ve kuruluşlar tarafından genellikle yıl bazlı olarak yapılmış Erzurum iline ait şehir, bölge planlama, çevre, afet müdahale planı vb. raporları ile farklı disiplinlere ait akademik çalışmalar, teknik raporlar incelenmiş ve ulusal basın taranmıştır.

\section{BULGULAR}

\subsection{Ciı̆}

Türkiye için afet yaratma potansiyeline sahip önemli bir doğa olayı olan çı̆̆; topoğrafik, jeolojik, jeomorfolojik, meteorolojik koşullar gibi doğal faktörlere bağlı olarak oluşabildiği gibi özel oluşumlar ve insani aktivitelere bağlı suni faktörler nedeniyle ile de oluşabilmektedir. Türkiye sınırları içerisinde gelişen çığ olaylarının çoğunlukla yerleşim bölgelerini etkilemeyen kırsal alanlarda meydana gelmesi, yaşanan maddi ve manevi kayıpların görece olarak diğer doğa olaylarına göre daha az olması nedeniyle Türkiye'de çı̆̆ olgusunun önemi, yaratabileceği tehlike ve risk potansiyeli göz ardı edilmektedir. Ancak, Türkiye'nin tamamı için tehlike ve risk yaratma potansiyeline sahip olmayan çı̆̆ olgusunun yoğun kar yağışına maruz kalan bitki örtüsü bakımından zayıf, dik ve eğimli topografyaya sahip dağlık alanlar için yaratabileceği bölgesel tehlike ve risk potansiyeli göz ardı edilmemelidir. Son olarak 4-5 Şubat 2020 tarihlerinde meydana gelen ve 42 kişinin ölümüyle sonuçlanan 2020 Van Çı̆̆ Faciası çığ olayının önemini ve ciddiyetini gözler önüne sermektedir. Normal şartlar altında çığ düşmesi yerleşim alanlarından uzak, yoğun kar yağışı alan havzanın yukarı kesimlerinde görülen bir doğa olayıdır. Ancak son yıllarda nüfusun artması, teknolojinin ve ulaşım imkânlarının gelişmesiyle yukarı havzalar da yerleşime uygun hale gelmeye başlamıştır. Bu durumun bir doğal sonucu olarak da meydana gelen çığ olayları sosyoekonomik ve sosyo-kültürel kayıp yaratma potansiyeline sahip bir doğa olayı şekline evrilmeye başlamıştır (Göl, 2005).

Başta topoğrafik ve iklimsel özellikleri olmak üzere çığ oluşumu için uygun bir ortama sahip olduğu bilinen çalışma alanı içerisinde 1900-2019 yılları arasında meydana gelen çı̆ olayları detaylı bir biçimde araştırılmıştır. Veri tabanları ve ulusal basın eş zamanlı olarak incelenmiş, tespit edilen olayların oluşum nedenleri, etki ve sonuçlarına ait raporlar karşılaştırılmıştır. Yapılan araştırma sırasında çalışma alanı içerisinde meydana gelen çok sayıda çığ olayının veri tabanlarına girmediği görülmüştür. Bu nedenle öncelikle çalışma alanı içerisinde meydana gelen, ulusal ve uluslararası afet veri tabanlarında bulunmayan ölüm ile sonuçlanan çığ olaylarına ait bilgiler Tablo 1'de verilmiştir.

Çı̆g olayları araştırılırken veri tabanlarında yer alan bilgilere ilişkin daha detaylı araştırma yapılması gereken bazı olaylar tespit edilmiştir. Örneğin; AKOMAS veri tabanında 04.03.2008 tarihinde Eğerli Dağı'nda (Palandöken) kayak yapan 13 kişinin üzerine çı̆̆ düştüğü ve 11 kişinin hayatını kaybettiği, çığ altında kalan 2 kişinin ise jandarma timleri tarafından sağ kurtarıldığı belirtilmiştir (URL 4). Ancak böylesine yakın tarihli bir doğa olayına ait can kaybı ile ilgili herhangi bir bilginin diğer arşiv tabanlarında ve ulusal basında yer almaması rapor ile ilgili bir hata olabileceğini düşündürmüştür. Yapılan detaylı araştırma sonucunda yerel ve ulusal basın ile birlikte TABB veri tabanında da yer alan bu çı̆̆ düşmesi olayında yaralı bilgisine ulaşılmış ancak herhangi bir ölüm bilgisine ulaşılamamıştır. Bu nedenle yapılan çalışmada bu çı̆̆ olayına ait 
bilgiler için AKOMAS veri tabanı rapor bilgileri kullanılmamıştır. Çalışma kapsamında çığ olayı ile ilgili bir başka dikkat çekici veri ise TABB kayıtlarında görülmektedir. TABB raporlarında çı̆̆ nedeni ile 9 kişinin hayatını kaybettiği belirtilirken olaylara ait afet sorgusu yapıldığında yine TABB kayıtlarında toplam 15 kişinin hayatını kaybettiği görülmektedir (URL 5). Bu karışıklık TABB analiz modülü alt bileșenleri olarak tanımlanan afet sorgu ve rapor bölümlerinin birbiri ile uyumsuz olmasından kaynaklanmaktadır.

Tablo 1. Ulusal ve uluslararası veri tabanlarında yer almayan ölümle sonuçlanan çı̆̆ olayları

\begin{tabular}{|c|c|}
\hline Tarih* & Açıklama \\
\hline 16.02.1956 & Hınıs Güzeldere Köyü üzerine çığ düşmüştür. 20 kişi hayatını kaybederken, 6 kişi kaybolmuştur (URL 2, URL 3). \\
\hline 26.04.1965 & Çat'da çığ altında kalarak öldüğü tahmin edilen cansız bir beden bulunmuştur (URL 3). \\
\hline 23.12.1974 & $\begin{array}{l}\text { Palandöken Dağı'nda } 6 \text { kişi çı̆̆ altında kalırken, yardım ekiplerinin de ikinci bir çı̆̆ kopması olayına maruz kalması } \\
\text { nedeniyle yaralanmalar meydana gelmiştir (URL 2, URL 3). }\end{array}$ \\
\hline 19.12.1977 & $\begin{array}{l}\text { Palandöken Dağı Ejder Tepesinde } 8 \text { kişi çı̆̆ altında kalmıștır. Palandöken Dağı'nda } 1976 \text { yılında } 1 \text { kişi, } 1975 \text { yılında } \\
\text { ise } 4 \text { kiși çı̆̆ nedeniyle hayatını kaybetmiștir (URL 2, URL 3). }\end{array}$ \\
\hline 23.02.1983 & Hınıs'da 4 kişi hayatını kaybetmiştir (URL 2). \\
\hline 04.02.1988 & Tortum'da 1 kişi hayatını kaybetmiştir (URL 2). \\
\hline 28.02.1990 & Tekman'da 1 kişi hayatını kaybetmiştir (URL 2). \\
\hline 29.01.1993 & Köprüküy'de 4 kişi üzerine çı̆̆ düşmüş, 1 kişinin cesedi çıkartılmıştır (URL 2). \\
\hline 08.03.1994 & Şenkaya'da askeri tim üzerine çı̆̆ düşmüş, 1 er hayatını kaybetmiştir (URL 2). \\
\hline 02.01.2006 & Palandöken Dağı’nda düşen çığın altında kalan bir turist hayatını kaybetmiştir (URL 3). \\
\hline
\end{tabular}

*Ulusal basında yer alan olay ve tarihler kullanılmıștır.

Veri tabanlarında yer bulmayan ancak ulusal basın arşivlerinde yer edinen ölüm ile sonuçlanan çığ olaylarının varlığı ve var olan verilerin yarattığı güvensizlik çığ tehlikesi varlığı bilinen çalışma alanı için şimdiye kadar yapılan çalışmaların önemli bir noktada eksik kaldığını göstermektedir. Bu nedenle çalışma alanı için kapsamlı bir çığ veri envanteri oluşturulmuştur. Çalışma alanına ait çı̆̆ veri envanteri oluşturmak için yapılan araștırmalarda meydana gelen çığ olayları sonrasında ölü ve yaralı sayısı dışında kayıp sayısı olarak da ilave bilgilerin verildiği olaylara rastlanılmıștır. Belirtilen kayıp sayıları ile ilgili güncel ve güvenilir bir bilgiye ulaşılamadığı için yapılan çalışmada bu veriler kullanılmamıștır. Kayıp olarak belirtilen bu verilere ait sağ, yaralı ya da ölü olarak güncel bilgilere ulaşılamaması doğa olayları ve doğal afet çalışmaları için bir başka eksiklik olarak değerlendirilmektedir.

Oluşturulan çığ envanterine göre; çalışma alanı içerisinde 1900-2019 yılları arasında meydana gelen çı̆̆ olaylarının Palandöken ve İspir ilçelerinde yoğunlaştığı, çı̆̆ olayına bağlı ölüm olaylarının ise Hınıs ve Palandöken ilçelerinde yoğun olduğu görülmüştür. Buna karşılık Aziziye, Karaçoban, Oltu, Olur, Pazaryolu ve Uzundere ilçelerinde herhangi bir çığ olayı kaydına ulaşılamamıştır. Elde edilen bu veriler ışığında çalışma alanı için çığ yoğunluk haritası oluşturulmuştur (Şekil 1). Oluşturulan çığ yoğunluk haritasında çığ olaylarının ilçe bazlı oluşum sayılarına göre çı̆̆ tehlikesinin benzer olduğu ilçeler gruplandırılmıştır.

Çalışma alanının büyük bir çoğunluğunda görülen çığ olayının oluşum sayısı ile ölüm sayısı arasında Palandöken ilçesi dışında anlamlı bir ilişki bulunmamaktadır. Örneğin; çığ olayının çok yoğun yaşandığı İspir ilçesinde hiçbir ölümlü olay rapor edilmez iken çığ olayının orta yoğun olduğu Hınıs ilçesinde 24 kişinin çığ nedeniyle hayatını kaybettiği bilgisine ulaşılmıştır. Elde edilen veriler ışığında, çalışma alanında çığ olayına bağlı can kayıplarının Palandöken ve Hınıs'da çok yoğun, Çat'da yoğun, Tekman'da orta yoğun ve son olarak Karayazı, Köprüköy, Narman, Pasinler, Şenkaya ve Tortum'da ise az yoğun olduğu belirlenmiştir. 


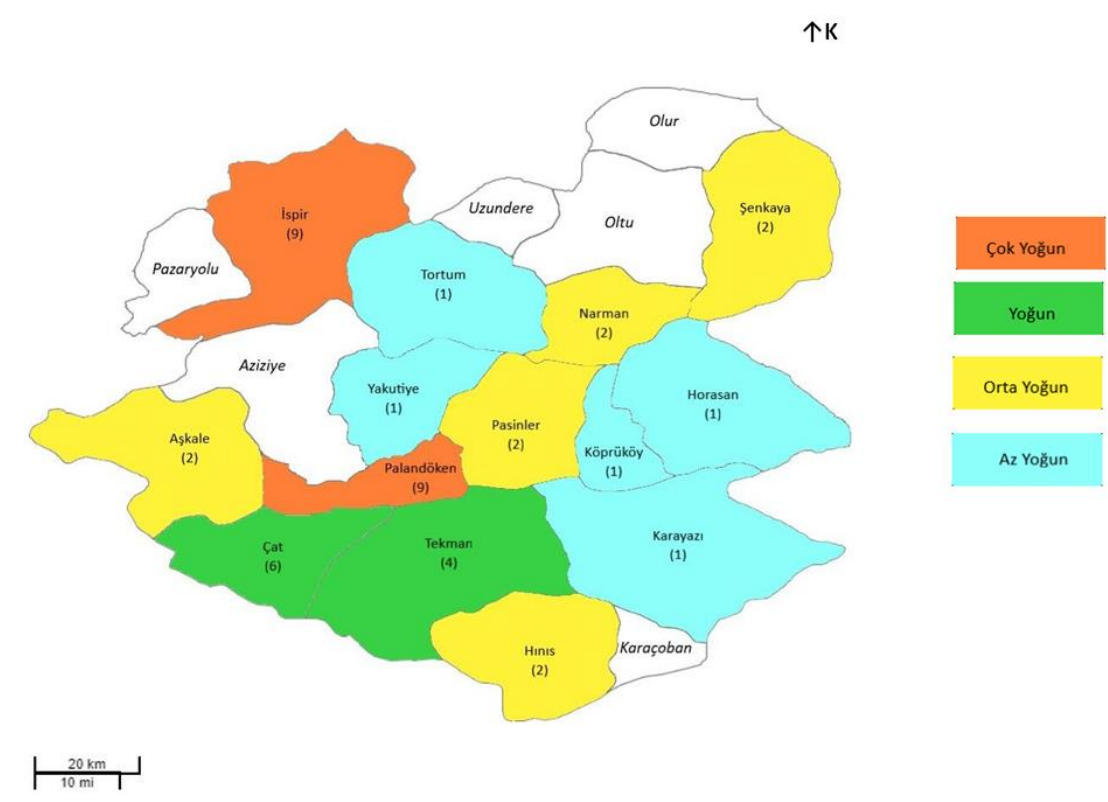

Şekil 1. Erzurum için çı̆̆ yoğunluk haritası

Sonuç olarak; çalışma alanı içerisinde gözlenen çı̆̆ oluşumlarının incelenmesiyle topoğrafik ve coğrafik koşulların yanı sıra hava sıcaklıklarındaki ani düşüşlerin, yoğun kar fırtınalarının ve tipinin; yani meteorolojik koşulların, çığ oluşumda oldukça etkili olduğu görülmüştür. Yetkililer tarafından özellikle kış aylarında çığ tehlikesi için sık sık uyarılan çalışma alanında deprem tetiklemesine bağlı olarak da çı̆̆ oluşumu gözlenmiştir. Örneğin; 16 Mart 1992 Pülümür deprem sonrası Tunceli-Erzurum Karayoluna ve 13 Mart 2005 Bingöl Karlıova'da meydana gelen depremin ardından ise Erzurum-Çat karayolunda çığ düştüğü rapor edilmiştir. Çı̆ğ oluşumlarının çoğunlukla yerleşim alanları dışında yer alan yol ayrımlarında ve/veya şehirlerarası karayollarında meydana gelmesi hem karayolu hem demiryolu ulaşımında çeşitli sorunların yaşanmasına neden olmaktadır.

\subsection{Deprem}

Türkiye'de; doğa olayları ve doğal afet ile ilgili yapılan çalışmaların büyük bir çoğunluğunu deprem ve deprem verilerinin bulunduğu birbirinden farklı amaçlara yönelik olarak yapılan çalışmalar oluşturmaktadır. Bu durum kuşkusuz Türkiye'nin dünyanın en yoğun deprem kuşaklarından biri olarak tanımlanan Alp-Himalaya Deprem Kuşağında yer almasından kaynaklanmaktadır. Türkiye topraklarının büyük bir çoğunluğu gibi Doğu Anadolu Bölgesi de jeolojik ve tektonik açıdan oldukça dinamik ve karmaşık bir yapıya sahiptir. Anadolu, Arap ve Afrika levhalarının birbirlerine göre hareketlerinin etkisi altında bulunan Doğu Anadolu Bölgesi sıkışma rejiminin hâkim olduğu bir bölgedir. Bölgede etkili olan sıkışma rejimi doğrultuları genellikle doğu-batı olan bindirmelerin, kuzeydoğu-güneybatı doğrultulu sol yönlü doğrultu atımlı fayların, kuzey-güney doğrultulu açılma çatlaklarının ve yaygın volkan çıkışlarının meydana gelmesine neden olmuştur (Şaroğlu ve Güner, 1981; Şaroğlu vd., 1987; Bozkuş ve Yılmaz, 1993). Bu süreç Doğu Anadolu'nun kabaca K-G yönünde daralıp, D-B yönünde uzamasına, kıta kabuğunun kalınlaşmasına ve bölgenin yükselmesine yol açmıştır. Sismolojik açıdan doğal bir laboratuvar alanı olarak kabul edilen Doğu Anadolu Bölgesi içerisinde yer alan Erzurum ve çevresi Kuzey Anadolu Fay Zonu ve Doğu Anadolu Fay Zonu'nun etkisi altında bulunmaktadır. Tarihsel ve aletsel dönemde önemli depremlerin yaşandığı çalışma alanı içerisinde gelecekte de büyük depremlerin yaşanılacak olması kaçınılmaz bir gerçektir. Bu durum; çalışma alanı içerisinde doğa olaylarının birbirleri ile özelliklede deprem ile ilişkilerinin belirlenmesi ihtiyacını doğurduğu gibi çalışma alanının güncel depremselliğinin ve deprem tehlikesinin belirlenmesinin gerekliliğini de ortaya 
koymaktadır. Bir bölgenin depremselliğinin ve deprem tehlikesinin belirlenebilmesi için belirli bir zaman diliminde meydana gelen depremlerin zaman ve uzay içerisindeki dağılımını tanımlayan deprem verilerine ihtiyaç duyulmaktadır. Bu çalışmada depremselliğin belirlenebilmesi için Erzurum merkez baz alınarak 130 km2'lik bir alan için, Kandilli Rasathanesi ve Deprem Araştırma Ensitüsü'den (KRDAE) elde edilen deprem verileri kullanılmıştır (URL 6). 1900-2019 yılları arasında çalışma alanı içerisinde meydan gelmiş olan depremler KRDAE kataloğundan seçilerek uygulanan standardizasyon işlemleri sonucunda çözümlemede kullanılacak yeni katalog elde edilmiştir. Oluşturulan yeni kataloğun homojen hale getirilmesi için [1-4] numaralı denklemlerde verilen ampirik bağıntılardan yararlanılmış olup, sonuç olarak Mw ölçeğinde homojen bir katolog elde edilmiştir (Gülal vd., 2011).

$$
\begin{aligned}
& \text { M_w }=1.117 * M \_b-0.387 \\
& M \_w=1.059 * M \_d-0.095 \\
& M \_w=1.027 * M \_l+0.048 \\
& M \_w=0.790 * M \_s+1.223
\end{aligned}
$$

Burada;

M_b: Cisim Dalgası Büyüklüğü, M_d: Süreye Bağlı Büyüklük, M_l : Yerel (Lokal) Büyüklük, M_s: Yüzey Dalgası Büyüklüğü ve Mw: Moment Büyüklüğü olarak tanımlanmaktadır.

Çalışma alanının aktif tektonik yapısının ve depremselliğinin net bir şekilde ortaya konulabilmesi için çalışma alanı içerisinde 1900-2019 yılları arasında meydana gelen Mw $\geq 3.5$ olan depremlerin episantr dağılım haritası Şekil 2'de verilmiştir.

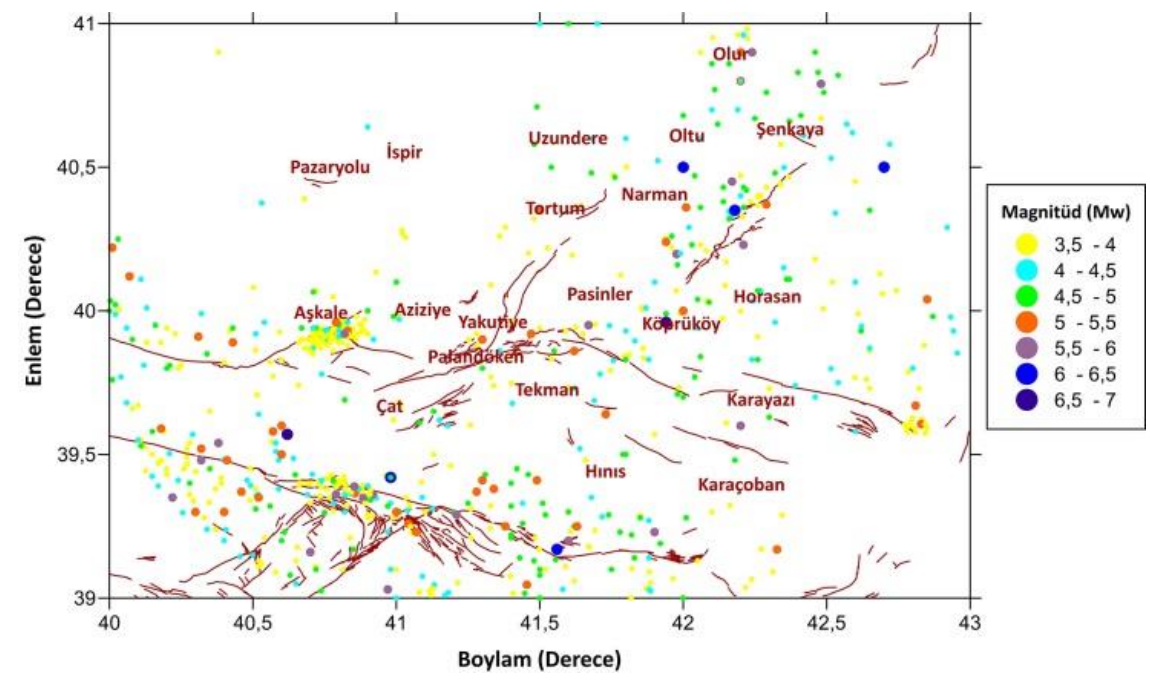

Şekil 2. 1900-2019 yılları arasında meydana gelen depremlerin episantr dağılım haritası

Çalışma alanı içerisinde meydana gelen $\mathrm{Mw} \geq 3.5$ olan depremler incelendiğinde; \%49.8'inin $3.5 \leq \mathrm{Mw}<4.0, \% 39,4$ 'ünün $4.0 \leq \mathrm{Mw}<5.0, \% 9.8$ 'inin $5 \leq \mathrm{Mw}<6, \% 1^{\prime}$ inin ise $6.0 \leq \mathrm{Mw}<7.0$ arasinda olduğu görülmektedir.

Çalışma alanı içerisinde 1900-2019 yılları arasında meydana gelen $M w \geq 3.5$ olan depremlerin derinlik dağılım haritası ise Şekil 3'de verilmiștir. 


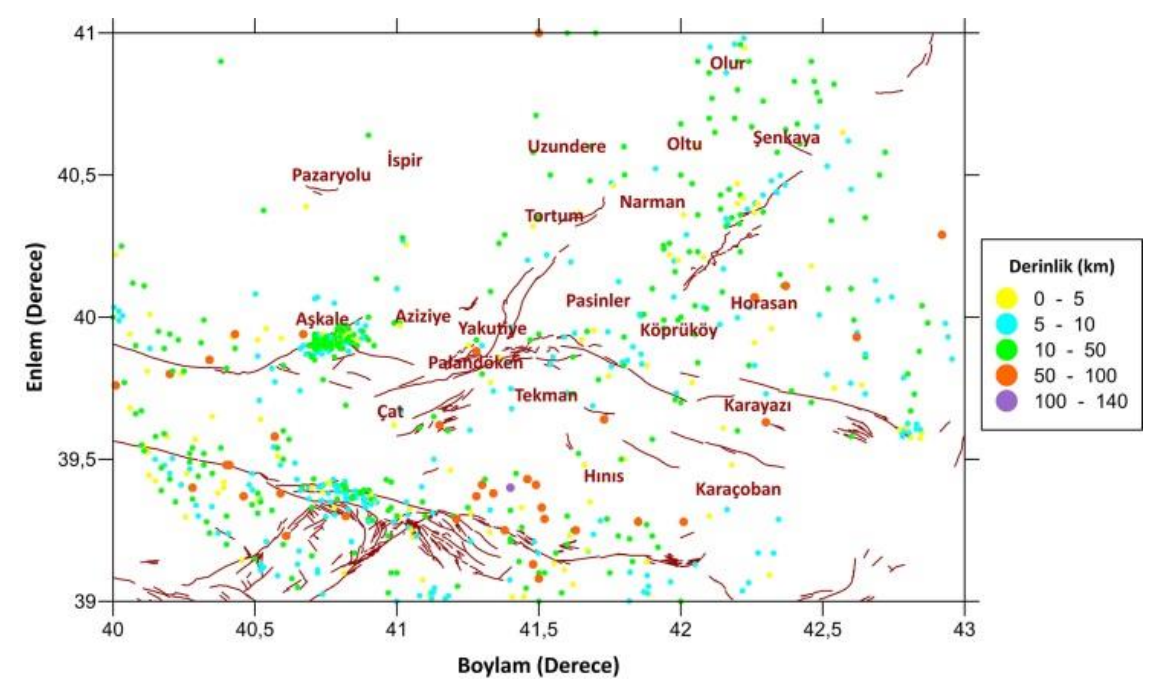

Şekil 3. 1900-2019 yılları arasında meydana gelen depremlerin derinlik dağılım haritası

1900-2019 yılları içerisinde meydana gelen depremlerin derinlik dağılımı incelendiğinde ise \%16.0'sının 0-5 km derinlikte, \%34.8'inin 5-10 km derinlikte, \%43.8'inin ise 10-50 km derinlikte ve \%5.4'ünün ise 50-140 km derinlikte meydana geldiği belirlenmiștir.

Çalışma alanı, Magnitüd-Frekans dağılımını belirlemek için Gutenberg-Richter bağıntısı (Gutenberg ve Richter, 1954);

$$
[\log N) \_M=a-b M
$$

kullanılmıştır.

Bu bağıntıda yer alan; N_((M)), M'ye eşit ya da daha büyük deprem sayısını, M büyüklüğü, Log ise 10 tabanına göre logaritmayı ifade etmektedir. "a" ve "b" regresyon katsayıları olarak tanımlanmaktadır. "a" katsayısı çalışma alanının genişliğine, gözlem dönemine ve deprem düzeyine bağlıdır. " $b$ " katsayısı ise deprem oluşumunun fiziği ile ilişkili bir parametre olarak ifade edilmektedir (Tabban ve Gencoğlu, 1975).

Sismik aktivite bakımından yoğun olan bölgelerde tehlike analizleri aracılığı ile depremlerin oluş sıklıklarının, tekrarlanma periyotlarının ve meydana gelme olasılıklarının tespit edilmesi yaygın olarak kullanılan bir mühendislik yaklaşımıdır. Yapılan bu çalışmada ise sahip oldukları avantajlar nedeniyle tehlike analizi amaçlı yapılan çalışmalarda sıklıkla kullanılan Gumbel ve Poisson modelleri kullanılmış, elde edilen sonuçlar birbiri ile karşılaştırmalı olarak değerlendirilmiştir.

Çalışma alanı için ilk olarak Gumbel Uç Değerler Metodu kullanılarak deprem tehlike analizi yapılmıştır. Bu metot, belli bir bölgede belirlenen zaman aralıklarında en büyük magnitüd değerleri kullanılarak maksimum büyüklükte depremlerin tahmini oluşma olasılıklarını hesaplayan istatistiksel bir yöntemdir. Bu yöntemin en önemli avantajı, deprem verilerinin eksik olması durumunda da kullanılabiliyor olabilmesinden kaynaklanmaktadır. Gumbel tarafindan geliştirilen modele göre (Gumbel, 1958); 


$$
G_{-}((M))=e^{\wedge}\left(\llbracket-\alpha e \rrbracket^{\wedge}(-\beta M)\right)
$$

Bu denklemde $M$ deprem büyüklügünü tanımlamakta olup $\alpha$ ve $\beta$ ise bölgenin sismisitesine bağlı katsayılardır. Gutenberg-Richter bağıntısındaki Denklem (5) a ve b katsayıları ile ilişkili olarak;

$$
\begin{aligned}
& \mathrm{a}=\log \alpha \text { veya } \alpha=10^{\wedge} \alpha \\
& \mathrm{b}=\beta \operatorname{Loge} \text { veya } \beta=b / \llbracket \log \rrbracket \_\mathrm{e}
\end{aligned}
$$

şeklinde formüle edilebilir. Bir yıl içinde oluşan M ve üzeri büyüklükteki deprem sayısı N_M;

$$
N_{-}((M))=\llbracket \alpha e \rrbracket \wedge(-\beta M)=-\ln G_{-}((M))
$$

formülü ile hesaplanmaktadır.

Çalışma alanı içerisinde yıllık maksimum magnitüdlerden en sık meydana gelen magnitüd değeri Modal Maksima (Mmodal) ise;

$$
\text { M_modal }=(\ln \alpha) / \beta
$$

formülü ile hesaplanmaktadır. Modelin uygulanma aşamasında öncelikle çalışma alanı içerisinde inceleme periyodu süresinde meydana gelen depremler içerisinden her bir yıl için en büyük magnitüdlü deprem belirlenmiştir. Deprem olayının meydana gelmediği yıllar için katalogdaki en küçük magnitüd aralığının $(4.0 \leq \mathrm{Mw} \leq 4.5)$ orta değeri $\mathrm{Mw}=4.2$ ortalama magnitüd değeri olarak kabul edilmiştir. Yapılan bu varsayım, çalıșma alanındaki yıllık ortalama magnitüd değerini tanımlayan Denklem (10) ile de doğrulanmıştır. Herhangi bir M magnitüdündeki depremin aşılma olasılığı R, Gumbel dağılımının 1'den farkı olarak ifade edilirken;

$$
R=1-G(M)=1-e^{\wedge}\left(\left(-\alpha^{*} e^{\wedge}\left(-\beta^{*} M\right)\right)\right)
$$

denklemi kullanılarak hesaplanır. Yıllık aşılma olasılı̆̆ının tersi olarak ifade edilen tekrarlanma periyodu (Tr);

$$
\mathrm{T}_{-} \mathrm{r}=1 / \mathrm{R}
$$

bağıntısı ile hesaplanmıştır. Çalışma alanı için hesaplanan tekrarlanma periyodu-magnitüd ilişkisi değerleri grafik halinde Șekil 4'de sunulmuștur.

Gumbel Dağılımı ile incelenen 130 km çaplı çalışma alanının yapı ömrü-magnitüd-risk ilişkisini hesaplamak amacıyla herhangi bir M büyüklügündeki depremin; t yıl için hesaplanacak deprem tehlikesi ise;

$$
R_{-} t=1-e^{\wedge}(-N(M)(t))
$$

olarak hesaplanır. 


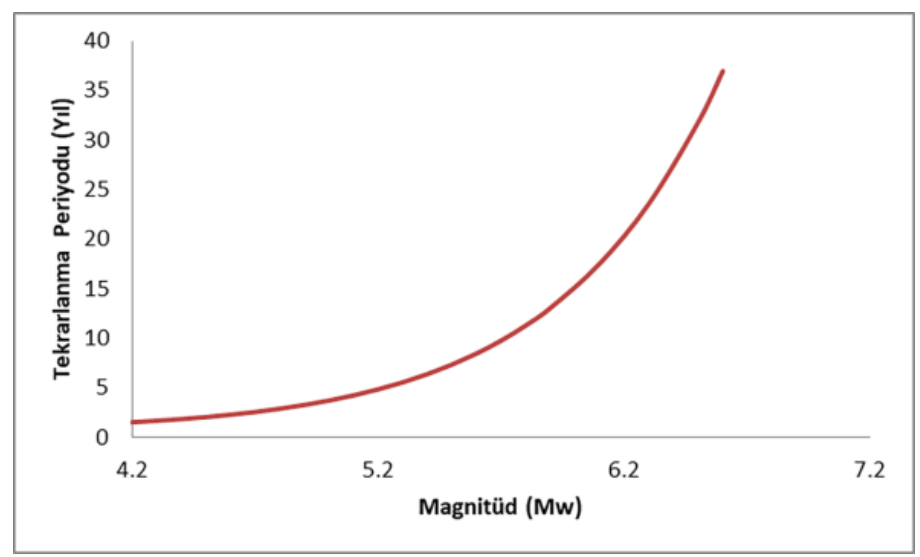

Şekil 4. Gumbel dağılımından elde edilen tekrarlanma periyodu-magnitüd ilişkisi

Çalışma alanı için M büyüklüğündeki depremin R1,R5,R10,R15,R20 ve R25 yıllık oluşma tehlike değerleri de hesaplanarak Şekil'5 de grafik olarak verilmiştir.

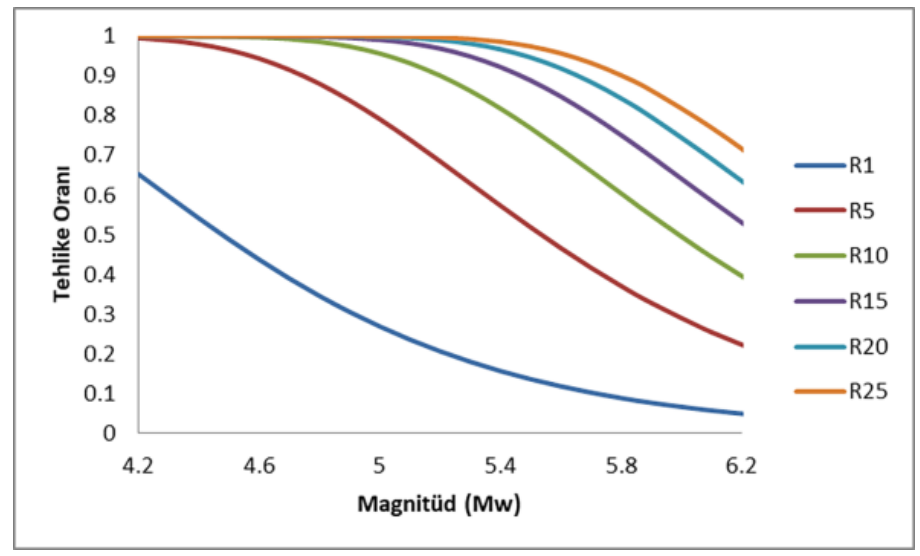

Şekil 5. Gumbel dağılımından elde edilen tehlike oranı-magnitüd ilişkisi

Sonuç olarak çalışma alanı için Gumbel Dağılımı sonuçlarını genel hatları ile Tablo 2'de özetlemek mümkündür.

Tablo 2. Gumbel dağılımından elde edilen tekrarlanma periyodu ve tehlike oranı değerleri

\begin{tabular}{cccccccc}
\hline Mw & Tr & R1 & R5 & R10 & R15 & R20 & R25 \\
\hline $\mathbf{5 . 0}$ & 3.72 & 0.26 & 0.79 & 0.95 & 0.99 & 0.99 & 0.99 \\
$\mathbf{5 . 5}$ & 7.34 & 0.13 & 0.51 & 0.76 & 0.88 & 0.94 \\
$\mathbf{6 . 5}$ & 31.81 & 0.03 & 0.14 & 0.27 & 0.38 & 0.47 \\
$\mathbf{6 . 6}$ & 36.96 & 0.02 & 0.12 & 0.23 & 0.33 & 0.42 & 0.54 \\
\hline
\end{tabular}

Çalışma kapsamında deprem tehlike analizinin yapılabilmesi için kullanılan bir diğer yöntem ise Poisson Dağılımıdır. Poisson modeli depremlerin hem mekan hem de zaman açısından birbirinden bağımsız bir şekilde meydana geldikleri varsayımına dayanmaktadır. Ancak, Poisson modelinin gerektirdiği bu koşulun sağlanması ve modelin uygulanılmasında sağlıklı sonuçların alınabilmesi 
için ana deprem ve bağımlı olayların net bir şekilde belirlenmesi gerekmemektedir. Yapılan bu çalışmada; artçı şok, öncü şok veya deprem yığılımları gibi bağımlı olayların deprem kataloğundan ayrıştırılması işlemi için birçok araştırmacı tarafından tercih edilen ve Wiemer tarafından geliştirilen (Wiemer, 2001) ZMAP yazılımı kullanılarak Reasenberg algoritması (Reasenberg, 1985) kullanılmış olup, homojen yeni bir katalog elde edilmiştir.

Poisson modelinde (Poisson, 1983) deprem olma olasılığı hesaplanırken, bir yıldaki M ve M'den büyük deprem sayısı n(M), T araştırılan incelenen zaman periyodu, deprem tehlike parametreleri $\mathrm{a}^{\wedge}{ }^{\prime}, \mathrm{a} \_1, \mathrm{a}_{-} 1^{\wedge}{ }^{\prime}$, tekrarlanma periyodu $\mathrm{T}_{-} \mathrm{r}, \mathrm{t}$ yll için deprem tehlikesi ise R_t olmak üzere;

$$
\begin{aligned}
& \mathrm{a}^{\wedge^{\prime}}=\mathrm{a}-\log \text { (bln10) } \\
& \text { a_1=a-log: } \\
& \text { a_ } 1^{\wedge^{\prime}}=\mathrm{a}^{\wedge^{\prime}}-\log \mathrm{T} \\
& n(M)=10^{\wedge}\left(a_{-} 1^{\wedge '}-b M\right) \\
& \mathrm{T}_{-} \mathrm{r}=1 / \mathrm{n}(\mathrm{M}) \\
& \mathrm{R}_{-} \mathrm{t}=1-\mathrm{e}^{\wedge}\left(-\mathrm{n}(\mathrm{M})^{*} \mathrm{t}\right)
\end{aligned}
$$

şeklinde ifade edilmektedir.

Yapılan analizler sonucunda çalışma alanı için belirli magnitüd değerlerinin tekrarlanma periyodları belirlenmiştir (Şekil 6).

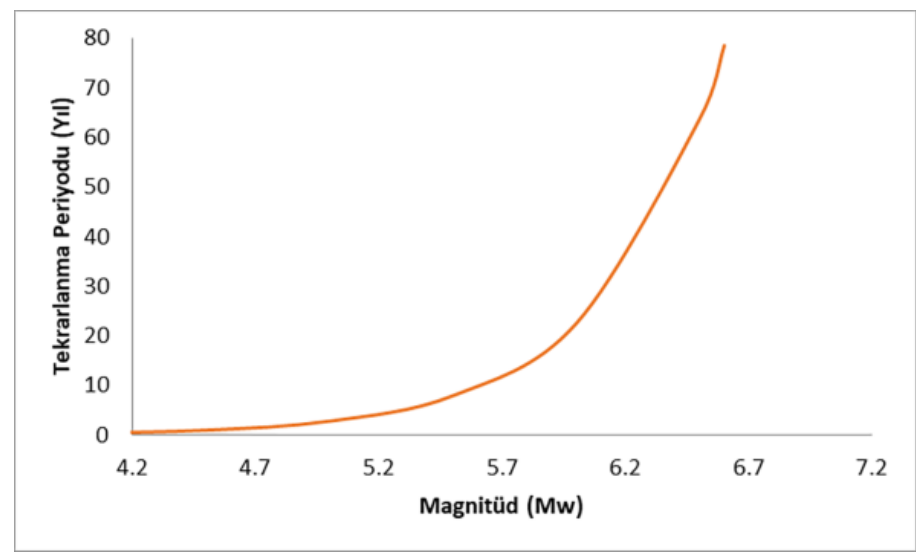

Şekil 6. Poisson dağılımından elde edilen tekrarlanma periyodu-magnitüd ilişkisi

Çalışma alanı için M büyüklügündeki depremin R1, R5, R10, R15, R20 ve R25 yıllık oluşma tehlike değerleri de hesaplanarak Şekil 7'de grafik olarak verilirken, çalışma alanı için Poisson Dağılımı sonuçları genel hatları ile Tablo 3'de sunulmuştur. 


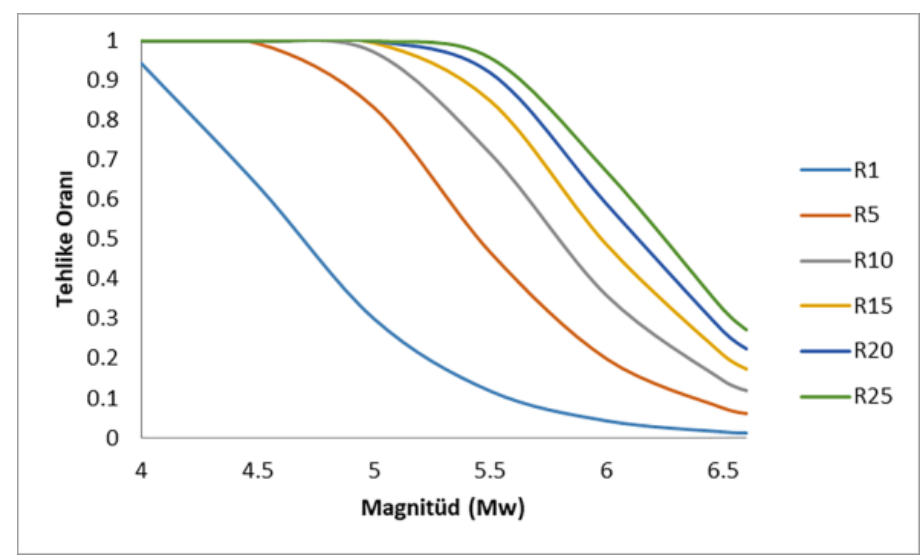

Şekil 7. Poisson dağılımında elde edilen tehlike oranı-magnitüd ilişkisi

Tablo 3. Poisson dağılımından elde edilen tekrarlanma periyodu ve tehlike oranı değerleri

\begin{tabular}{lccccccc}
\hline Mw & Tr & R1 & R5 & R10 & R15 & R20 & R25 \\
\hline $\mathbf{5 . 0}$ & 2.80 & 0.30 & 0.83 & 0.97 & 0.99 & 0.99 & 0.99 \\
$\mathbf{5 . 5}$ & 7.93 & 0.11 & 0.46 & 0.71 & 0.84 & 0.91 & 0.95 \\
$\mathbf{6 . 5}$ & 63.71 & 0.015 & 0.07 & 0.14 & 0.20 & 0.26 & 0.32 \\
$\mathbf{6 . 6}$ & 78.47 & 0.012 & 0.06 & 0.11 & 0.17 & 0.22 & 0.27 \\
\hline
\end{tabular}

Sonuç olarak; çalışma alanı içerisinde 25 ylllık bir süreç içerisinde $M=6.6$ büyüklüğündeki bir depremin oluşma olasılığı Gumbel Dağılımı'na göre \%49 iken Poisson Dağılımı'na göre bu olasılık \%27'dir. Yine aynı şekilde Mw=6.6 olan bir depremin tekrarlanma periyodu ise Gumbel Dağılımı'na göre 36.96 yıl iken Poisson Dağılımı'na göre ise 78.47 yıl olarak belirlenmiştir.

İki modelden elde edilen sonuçlar karşılaştırmalı olarak Şekil 8'de verilmiştir.

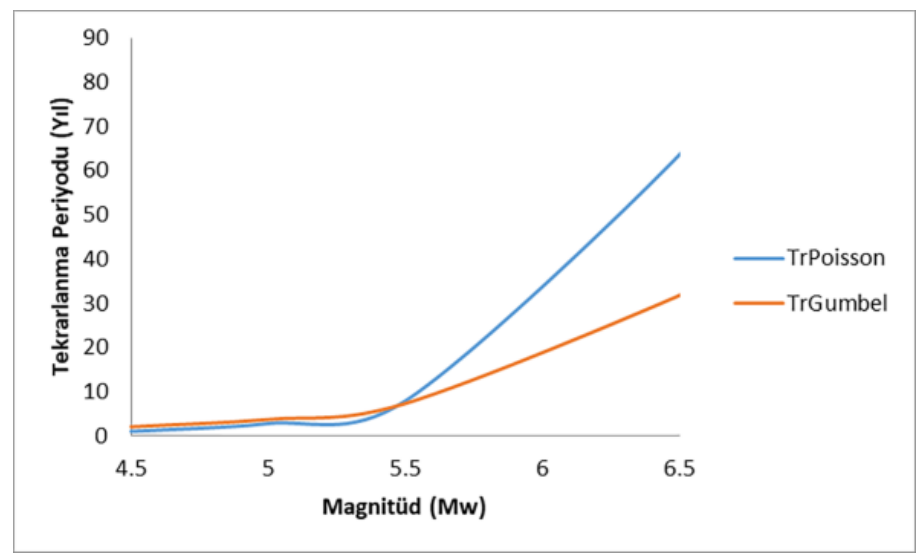

Şekil 8. Gumbel ve Poisson dağılımlarından elde edilen tekrarlanma periyodu-magnitüd ilişkisi

Çalıșma alanı için Gumbel ve Poisson Dağılım Modellerinin en genel ifade ile $5.5 \leq \mathrm{Mw} \leq 6.0$ aralığındaki depremler için farklılık göstermeye başladığını, Mw $\geq 6.0$ olan depremler için bu 
farklılı̆̆ın belirginleştiğini söylemek mümkündür. Mw $\leq 5.5$ olan depremlerde ise sonuçlar nispeten birbirine yakın sonuçlar vermektedir. Bu durum; toplam deprem veri seti içerisinde $\mathrm{Mw} \geq 5.5$ deprem verisi yoğunluğun az olmasından kaynaklanmaktadır.

Literatürde de yaygın bir şekilde kabul edildiği üzere, Poisson modeli her durumda diğer modellere kıyasla daha emniyetli tarafta deprem tehlikesi sonuçlarını doğurmaktadır (Jordanovski ve Todorovska, 1994). Poisson ve Markov modelleri karşılaştırılarak yapılan çalışmada sık ve orta büyüklükte deprem oluşumlarını içeren bölgelerdeki deprem tehlikesinin tahmini için Poisson modelinin yeterli olduğu ifade edilmiştir (Kiremidjian, 1982). Yine aynı şekilde yapılan istatistiksel çalışmalar neticesinde Poisson modelinin orta ve büyük depremler için geçerli olduğu belirtilmiştir (Akol, 2009). Bu nedenle, özellikle büyüklüğü $M \geq 6.0$ olan depremler için Poisson dağılımı sonuçlarının dikkate alınması daha doğru bir yaklaşım olacaktır (Akol ve Bekler, 2013).

\subsection{Heyelan}

Heyelan, dünya genelinde depremden sonra oldukça dikkat çeken, yüksek tehlike ve dolayısı ile de risk oluşturabilme potansiyeline sahip önemli doğa olaylarından biri olarak kabul edilmektedir. Kimi zaman çok yavaş kimi zaman çok hızlı bir şekilde meydana gelen heyelanlar; jeolojik, topoğrafik ve çevresel koşullar olarak adlandırılan hazırlayıcı faktörlere (ortam faktörleri) bağlı olarak oluşabildikleri gibi tetikleyici faktörlere yani deprem, yağıș ve insani faaliyetlere bağlı olarak da oluşabilmektedirler. Hem hazırlayıcı faktörlere hem de tetikleyici faktörlere bağlı olarak oluşabilen heyelanlar nedeniyle yaşanabilecek kayıpların azımsanmayacak boyutlara ulaşabildiği bilinen bir gerçektir. Özellikle uzun süreyle bol yağışa maruz kalan, bitki örtüsünün zayıf olduğu, tektonik açıdan aktif bölgelerde meydana gelen aşırı yağış, sel, deprem gibi ilksel doğa olayları hızla tehlike ve risk durumu yaratabilmekte ve sonuç olarak da yeni bir doğa olayının sıklıkla da heyelanın oluşmasına sebep olabilmektedir. Oluşan heyelan ise ilksel doğa olayının zarar verme kapasitesini arttırmakta ve dolayısı ile yarattığı ikincil hasarlara bağlı olarak yerleşim alanları için yeni kayıpların ve problemlerin oluşmasına aynı zamanda da müdahale çalışmalarında aksaklıkların yaşanmasına neden olmaktadır.

Türkiye'de heyelan denilince akla ilk olarak Karadeniz Bölgesi gelse de Doğu Anadolu Bölgesi'nde de meydana gelen heyelanlar azımsanmayacak sayıda ve önemdedir. Çalışma alanının lokasyon açısından Karadeniz Bölgesi'ne yakın olmasına bağlı olarak yer yer bazı bölgelerde nispeten Karadeniz iklimine benzer iklimsel özelliklerin görülmesi, coğrafik ve topoğrafik koşulları heyelan olgusunun bölge için göz ardı edilemeyecek bir doğa olayı olduğunu ortaya koymaktadır. Ancak bu bölgede meydana gelen heyelanların oluşum periyodları Karadeniz Bölgesi kadar kısa olmamakta, görece olarak daha uzun zaman dilimlerine yayılmaktadır. Çalışma alanı içerisinde heyelan yoğunluğunun fazla olmasının nedeni iklimsel özellikler ile heyelana duyarlı kırıntılı birimlerin yaygın olarak yüzeylenmesi ve engebeli arazi koşulları olarak ifade edilmektedir (Çan vd., 2013).

Bölgenin bilinen aktif tektoniği, heyelan oluşum potansiyeli ve son yıllarda deprem ile heyelan arasındaki ilişkiye yönelik çalışmaların artması nedeniyle bu çalışmada da öncelikle çalışma alanı içerisinde meydana gelen deprem aktivitesine bağlı olarak oluşan heyelan olayları tespit edilmiş ve elde edilen bilgiler Tablo 4'de listelenmiştir.

Tablo 4'de de görüldüğü üzere çalışma alanı içerisinde meydana gelen deprem aktivitesine bağlı olarak oluşan heyelan olaylarının yarattıkları ikincil hasarlar ortaya konmuş ve ölüm ile sonuçlanan herhangi bir olaya rastlanmamıştır. Aslında Türkiye'de her ne kadar deprem aktivitesine bağlı heyelan oluşumları sıklıkla yaşanıyor olsa da bu nedenle herhangi bir can kaybı olayı rapor edilmemiştir (Fidan, 2019). Buna karşılık, çalışma alanı içerisinde deprem aktivitesine bağlı olarak oluşan heyelan olaylarının yardım ve kurtarma çalışmaları için önemli bir problem 
oluşturduğu görülmektedir. Bu durumun bir sonucu olarak, aktif tektonik yapısı ile bilinen çalıșma alanı için ileride daha büyük sorunların yaşanmaması için heyelan ile ilgili yapılacak farklı disiplinlere ait tüm çalışmalarda deprem aktivitesinin de hesaba katılması gerektiği unutulmamalıdır.

Tablo 4. Deprem aktivitesine bağlı olarak meydana gelen önemli heyelan olayları

\begin{tabular}{|c|c|}
\hline Tarih & Açıklama \\
\hline 1850 & VII şiddetindeki deprem yer yarılmaları ve heyelan oluşumlarına neden olmuştur (URL 7). \\
\hline 13.09.1924 & $\begin{array}{l}\text { Ms=6.8 büyüklüğündeki depremle hareket eden heyelan ve kaya düşmeleri ilave hasar yaratmıştır (Aksu, } \\
\text { 2014). }\end{array}$ \\
\hline 30.10 .1983 & $\begin{array}{l}\text { Ms=6.9 büyüklüğündeki depremden sonra meydana gelen artçı sarsıntılar ile birlikte heyelan olayları da } \\
\text { yaşanmıştır. Karayollarında ve demiryollarında heyelan nedeniyle hasar meydana gelmesi yardım } \\
\text { çalışmalarını sıkıntıya sokmuş ve bazı bölgelere helikopter ile kurtarma ekipleri gönderilmiştir (URL 3). }\end{array}$ \\
\hline 13.09.1984 & $\begin{array}{l}\mathrm{Mb}=6.4 \text { büyüklüğündeki deprem nedeniyle Şenkaya ilçesine bağlı köylerde heyelana elverişli yamaçlarda } \\
\text { yamaç eğimine paralel çekem çatlakları gelişmiş ve çok sayıda kaya düşmeleri meydana gelmiştir. Deprem } \\
\text { hasarının artmasında heyelan ve kaya düşmeleri önemli rol oynamıştır (Aksu, 2014). }\end{array}$ \\
\hline 29.05.2001 & $\mathrm{M}=4.6$ büyüklüğündeki depremden sonra yapılan hasar tespit çalışmalarında en fazla hasar gören \\
\hline & Pasinler'in Yukarı Çakmak Köyü’nün 1982 yılında heyelan bölgesi ilan edildiği belirtilmiştir (URL 3). \\
\hline 25-28.03.2004 & $\begin{array}{l}\text { Mw=5.4 olan Aşkale depremleri meydana getirdikleri yer ivmesiyle sahada farklı lokasyonlarda çeşitli tipte } \\
\text { kütle hareketlerinin tetiklenmesine neden olmuştur. Tetiklenen heyelanların depremin aletsel ve } \\
\text { makrosismik episantral bölgesine rastladığı belirtilmiştir. Yapılan inceleme sonucunda bölgedeki diğer } \\
\text { heyelan kütlelerinde tetiklenme yolu ile stabilitenin bozulmuş olabileceği düşünülmüştür. Sonuç olarak, } \\
\text { deprem sonrasında bölgedeki heyelanların reaktivitesinde artış olasıllığından bahsedilmiştir (Doğan vd., } \\
\text { 2004). }\end{array}$ \\
\hline 12.03.2005 & $\begin{array}{l}\text { Ml=5.7 Bingöl depremi sonrası Erzurum-Karlıova yolunda oluşan heyelan ulaşım sorunlarına yol açmıştır } \\
\text { (URL 3). }\end{array}$ \\
\hline
\end{tabular}

Yapılan çalışmada, envanter oluşturulması sırasında ise DesInventar kayıtlarında yer alan ve 4 kişinin hayatını kaybettiği raporlanan 21.07.1988 tarihli heyelan olayı dikkat çekici bulunmuştur (URL 8). Çalışma alanı içerisinde meydana gelen diğer heyelan olaylarında herhangi bir can kaybının olmaması ve bu tarihli heyelanın diğer veri tabanlarında yer bulmaması nedeniyle 21.07.1988 tarihli heyelan olayı detaylı olarak incelenmiştir. Yapılan araştırmada Türkiye'de 1988 yılında can kaybına neden olan iki adet heyelan verisine ulaşılmıştır. Bunlar, 23 Haziran 1988 tarihinde 64 kişinin hayatını kaybetmesine neden olan Trabzon Çatak Heyelanı ile 21 Temmuz 1988 tarihinde Rize'de aşırı yağışa bağlı olarak oluşan ve 3 kişinin hayatını kaybetmesine neden olan Rize Heyelanıdır. Bu tarih baz olarak yapılan araștırmalarda ise; 1988 yılı yaz aylarında Türkiye'de meydana gelen yağışların pek çok doğal afete neden olduğu, Çatak heyelanından sonra Trabzon ve Rize civarında heyelan oluşumlarının devam ettiği belirtilmiştir. Bu heyelanların oluşumunda birinci derecede etkili olan yağışların aynı dönem içerisinde Ankara, Samsun, Ordu, Giresun, Trabzon, Rize, Erzurum ve çevresinde önemli ölçüde can ve mal kayıplarına sebep olan su baskınlarını da oluşturduğu belirtilmiștir (Doğu vd., 1989). Yine DesInventar kayıtlarında bu tarih ile ilgili Pasinler ilçesinde 4 kişinin hayatını kaybettiği bir sel ve kaya düşmesi olayı rapor edilmiştir. Sonuç olarak, bu tarihte meydana gelen can kaybının heyelan veya kaya düşmesi nedeni ile değil aşırı yağışa bağlı sel oluşumu nedeni ile meydana geldiğine karar verilmiş ve bu veri yapılan çalışmada heyelan ve kaya düşmesi olayları içerisinde değil sadece sel olayı içerisinde değerlendirilmiştir.

Oluşturulan envantere göre, çalışma alanı için heyelan olayı yoğunluk haritası oluşturulmuş ve böylelikle heyelan oluşum sayılarının aynı ya da benzer olduğu ilçeler belirlenmiştir (Şekil 9).

Çalışma alanında 119 yıllık süreç boyunca heyelan olayının çok yoğun yaşandığı ilçeler İspir, Oltu, Şenkaya iken Karayazı, Pazaryolu, Tekman ve Yakutiye ilçelerinde heyelan olayına ait herhangi bir rapora ulaşılamamıştır. 


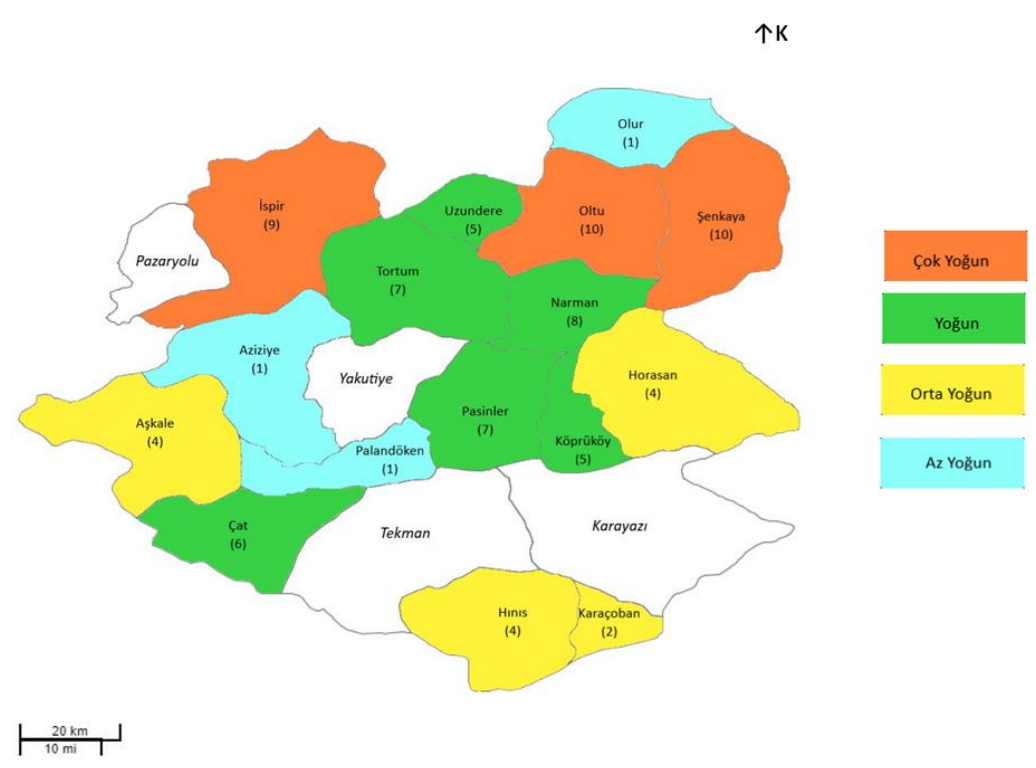

Şekil 9. Erzurum için heyelan yoğunluk haritası

Sonuç olarak; çalışma alanı içerisinde meydana gelen heyelanların incelenmesi sırasında deprem aktivitesi ve fay ilişkisi dışında hidrolojik kökenli doğa olaylarına bağlı heyelan oluşumlarının sıklıkla görüldüğü yine aynı şekilde ilksel doğa olayı olarak görülen heyelanların da diğer doğa olaylarının oluşumları için ortamda tetikleyici faktör oluşturdukları görülmüştür. Bu bağlamda sismik aktivite, yağıș ve bitki örtüsünün bölgedeki heyelan oluşumları üzerinde etkili olduğunu söylemek mümkündür.

\subsection{Kaya düşmesi}

Ani olarak gelișen tek veya sıralı olaylar șeklinde devam edebilme özelliğine sahip kaya düşmesi olayı; değişik boy ve türdeki kaya bloklarının ve/veya zemin parçalarının doğal yollarla ya da çeșitli faktörler nedeniyle belirli bir hareket yolu olmaksızın meyil aşağı hızla hareket etmesi sonucu meydana gelmektedir. Donma-erime, buz çatlaması, ısınma-soğuma, ıslanma-kuruma, bitkilerin çözülme etkileri gibi doğal faktörler nedeniyle oluşabilen kaya düşmelerinin meydana gelmesinde potansiyel tetikleyici faktörler olarak tanımlanan deprem, aşırı yağış ve heyelan olayları da oldukça önemlidir. Arazinin engebeli ve eğimli, bitki örtüsünün seyrek olduğu özellikle Erzurum gibi karasal iklimin hâkim olduğu, gece-gündüz sıcaklık farklılıklarının net bir şekilde hissedildiği alanlar kaya düşmesine elverişli alanlar olarak ön plana çıkmaktadır.

Çalışma alanının kaya düşmesi olayının oluşumu için oldukça uygun şartlara sahip olması nedeniyle çalışma alanı içerisinde 1900-2019 yılları arasında meydana gelen kaya düşmesi ile ilgili olaylar detaylı bir biçimde araștırılmıștır. Bu bağlamda; 2004 Așkale depremleri sonrasında yapılan çalışmalar dikkat çekici bulunmuştur. Yapılan incelemelerde deprem bölgesinde yer hareketi tetiklemesiyle oluşmuș az sayıda kaya düşmesi olayı belirlenmiş ve meydana gelen depremler öncesinde de iklimsel özelliklere bağlı olarak depremden bağımsız kaya düșmelerinin de meydana geldiği belirtilmiştir (Doğan vd., 2004). Ayrıca Tablo 4'de 13 Eylül 1924 ve 18 Eylül 1984 tarihlerinde meydana gelen depremler sonucunda kaya düşmelerinin gözlendiği ve meydana gelen hasarın artmasında heyelan ile birlikte önemli rol üstlendikleri ifade edilmiştir. Bölgenin aktif tektonik yapısı göz önüne alındığında deprem-heyelan, deprem-kaya düşmesi, heyelan-kaya düşmesi, deprem-heyelan-kaya düşmesi ilişkilerinin tespitinin oldukça önemli olduğunu ifade etmek mümkündür. Ancak genelde ilksel doğa olayının büyüklüğü, önemi ve/veya yarattığı hasar nedeniyle tetikleme etkisi ile oluşan doğa olayının yarattığı hasar göz ardı 
edilmektedir. Özellikle deprem gibi kuvvetli bir yer hareketi ana olay olarak meydana gelmiş ise ikincil doğa olayları ile ilgili bilgiye ulaşmak çoğu zaman sıkıntılı olmaktadır.

Çalışma alanı içerisinde meydana gelen doğa olaylarına ait envanter kaydının oluşturulması sırasında yaşanılan en büyük zorluğun kaya düşmesi ile ilgili sağlıklı veriye ulaşmak olduğunu söylemek mümkündür. Herhangi bir can kaybı olayına neden olmadığı için sistemli bir şekilde kayıt altına alınmadığı düşünülen kaya düşmesi olayına ait çalışma alanı için kapsamlı bir veri envanteri oluşturulamamıştır. Elde edilen veriler ışığında hazırlanan envantere göre Şekil 10'da çalışma alanı için kaya düşmesi oluşum sayılarına göre yoğunluk haritası oluşturulmuştur.

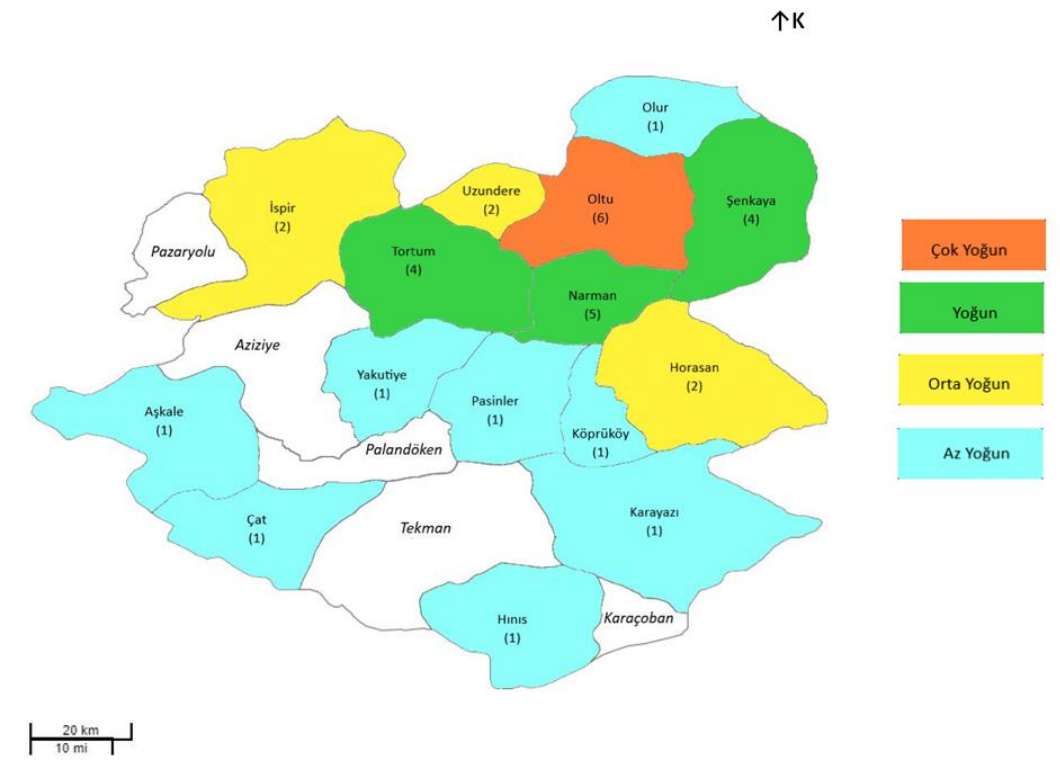

Şekil 10. Erzurum için kaya düşmesi yoğunluk haritası

Şekil 10'a göre kaya düşmesi olaylarının Oltu ilçesinde çok yoğun, Tortum, Narman ve Şenkaya ilçelerinde yoğun, İspir, Horasan ve Uzundere ilçelerinde orta yoğun, Așkale, Çat, Hınıs, Karayazı, Köprüköy, Olur, Pasinler ve Yakutiye ilçelerinde ise az yoğun olduğu görülmektedir.

Narman, Şenkaya, Pasinler, Oltu, ilçelerinde meydana gelen kaya düşmesi olayları incelendiğinde kaya düşmesi olayları ile birlikte rapor edilmiş heyelan ve su baskını olayları dikkat çekmektedir. Ancak birincil ve ikincil olaylara ait bilginin net şekilde belirtilmemiş olması nedeniyle kaya düşmelerinin doğal faktörlere bağlı olarak mı yoksa potansiyel tetikleyici faktörlere bağlı olarak mı geliștiği konusunda net bir değerlendirmede bulunmak mümkün olmamaktadır. İlksel doğa olayı olarak ve/veya aşırı yağış ve sele bağlı olarak oluşan kaya düşmesi olayları nedeniyle ulaşımda ve/veya kurtarma faaliyetlerinde kimi zaman aksaklıkların yaşandığı bilinen bir gerçek olmasına rağmen konu ile ilgili resmi kayıt sayısı oldukça azdır. Detaylı raporlara ulaşılamadığı için de başta deprem olmak üzere diğer doğa olayları ile kaya düşmesi arasındaki tetikleyici etki ilişkisi üzerine net bir değerlendirme yapılamamıştır.

En genel ifade ile çalışma alanı içerisinde meydana gelen kaya düşmesi olaylarında jeolojik ve topoğrafik özelliklerin etken olduğunu söylemek mümkündür.

\subsection{Sel}

Gerek çöl alanları gibi oldukça kurak alanlarda gerekse tropikal alanlar gibi oldukça nemli alanlarda meydana gelebilen seller yavaş, hızlı ve ani olarak gelișebilmekte oluşum yerlerine bağlı 
olarak dere ve nehir selleri, dağlık alan selleri, şehir selleri ve kıyı selleri olarak adlandırılmaktadırlar.

Türkiye özelinde ise sel oluşumu ve sonrasında meydana gelen sel afetinin doğal afetler içerisinde en sık karşılaşılan afetlerden birisi olduğunu söylemek mümkündür. Depremden sonra oldukça fazla can kaybına ve ekonomik zarara neden olan sellerin özellikle son yılarda artan şehirleşme faaliyetlerine bağlı olarak tekrarlanma aralıkları sıklaşmakta ve netice itibari ile de önemli oranda can kayıplarının ve ekonomik hasarın oluşmasına neden olmaktadırlar.

Sel oluşumunda temel faktör kuvvetli ve uzun süren yağışlar olsa da kar erimesi sonucu oluşan kuvvetli akışlar veya drenaj kanallarının tıkanmasına bağlı olarak da sel oluşumları meydana gelmektedir. Modern dünyada sel oluşumu ile ilgili en önemli sorun ise; kuvvetli ve yoğun yağmur firtınalarında drenaj sistemlerindeki yetersizlik sonucunda ana nehir kanallarının tamamen dolmasıyla meydana gelen taşmalar sonucu oluşan seller olarak kabul edilmektedir. Meydana geldiği bölgenin meteorolojik, topografik, jeolojik, jeomorfolojik şartlarına, arazi kullanım özelliklerine bağlı olarak meydana gelen sel oluşumlarında erozyon, ormansızlaşma, kontrolsüz yapılaşma gibi doğa dengesini bozucu insan girişimleri de etkili olmaktadır.

Son yıllarda kent sellerinde görülen artış ve çalışma alanının topoğrafik, meteorolojik ve iklimsel özellikleri başta olmak üzere sel oluşumu için uygun bir ortama sahip olması nedeniyle 1900-2019 yılları arasında meydana gelen sel olayları detaylı bir biçimde araştırılmıştır. Yapılan araştırma sırasında çığ olayında olduğu gibi çalışma alanı içerisinde meydana gelen çok sayıda sel olayının arşiv kayıtlarına girmediği görülmüştür. Bu nedenle çalışma alanı içerisinde meydana gelen, ulusal ve uluslararası afet veri tabanlarında bulunmayan ölüm ile sonuçlanan sel olaylarına ait bilgiler Tablo 5'de verilmiştir.

Tablo 5. Ulusal ve uluslararası veri tabanlarında yer almayan ölümle sonuçlanan sel olayları

\begin{tabular}{|c|c|}
\hline Tarih* & Açıklama \\
\hline 13.08 .1961 & Oltu'da 1 çocuk hayatını kaybetmiştir (URL 4). \\
\hline 24.07.1963 & Aziziye Gelinkaya'da 3 kişi, Yoncalık'da 1 kişi hayatını kaybetmiştir (URL 4). \\
\hline 25.07 .1963 & İspir'de 1 kişi, Tortum'da 4 kişi sele kapılmış ve kurtarılamamıştır (URL 4). \\
\hline 16.08 .1963 & Pasinler'de 1 çocuk boğularak hayatını kaybetmiştir (URL 3). \\
\hline 02.08 .1965 & Aziziye'de 2 kişi hayatını kaybetmiştir (URL 4). \\
\hline 22.04.1968 & İspir'de 1 kişi boğularak hayatını kaybetmiştir (URL 4). \\
\hline 01.09 .1974 & Hınıs'da sel baskını sonucu 2 kişi hayatını kaybetmiştir (14). \\
\hline 19.04.1988 & Hınıs'da 1 çocuk hayatını kaybetmiştir (URL 4). \\
\hline 29.04.1990 & Horasan' da sele kapılan 2 kişi kurtarılamamıştır (URL 4). \\
\hline 30.04.1992 & Horasan'da 2 çocuk hayatını kaybetmiştir (URL 3). \\
\hline 09.07.1999 & Aşkale'de 3 kişi hayatını kaybetmiştir (URL 9). \\
\hline 07.03.2004 & $\begin{array}{l}\text { Çat'a bağlı Değirmenli köyünde, kar erimesi sonucu sel ve çı̆̆ felaketi nedeniyle } 2 \text { ev tamamen } \\
\text { yıkılırken, } 3 \text { kişi akıntıya kapılarak hayatını kaybetmiştir (URL 10). }\end{array}$ \\
\hline 11.08.2005 & Palandöken'de 2 kişi hayatını kaybetmiştir (URL 3). \\
\hline
\end{tabular}

Diğer doğa olaylarında olduğu gibi çalışma alanı içerisinde meydana gelen sel olayları incelenirken de veri tabanlarında birbirinden farklı sonuçlarla ifade edilen olaylara rastlanılmıştır. Örneğin; 03.08.2007-05.08.2007 tarihinde Horasan'da meydana gelen sel nedeniyle DesInventar kayıtlarında 2 kişinin hayatını kaybettiği, ulusal basında 2 kişinin sulara kapılarak kaybolduğu, TABB arşivinde ise selde kaybolan 2 kişiyi arama çalışmalarının devam ettiği bilgisi yer almaktadır. Bu olayla ilgili olarak yapılan detaylı incelemelerde 2 kişinin sulara kapılarak hayatını kaybettiği sonucuna ulaşılarak değerlendirme yapılmıștır. 21.07.2010 tarihinde Horasan'da meydana gelen sel ile ilgili olarak ise; veri tabanları birbirinden farklı raporlamaya sahiptir. Yapılan detaylı araştırma sonucunda bu olay ile ilgili DesInventar kayıtlarının doğruluğu gözlenmiştir. 
Sonuç olarak çalıșma alanı için sel oluşum sayılarına göre sel yoğunluk haritası oluşturulmuștur (Şekil 11). Böylelikle sel/taşkın tehlikesinin aynı ya da benzer olduğu ilçeler belirlenmiştir.

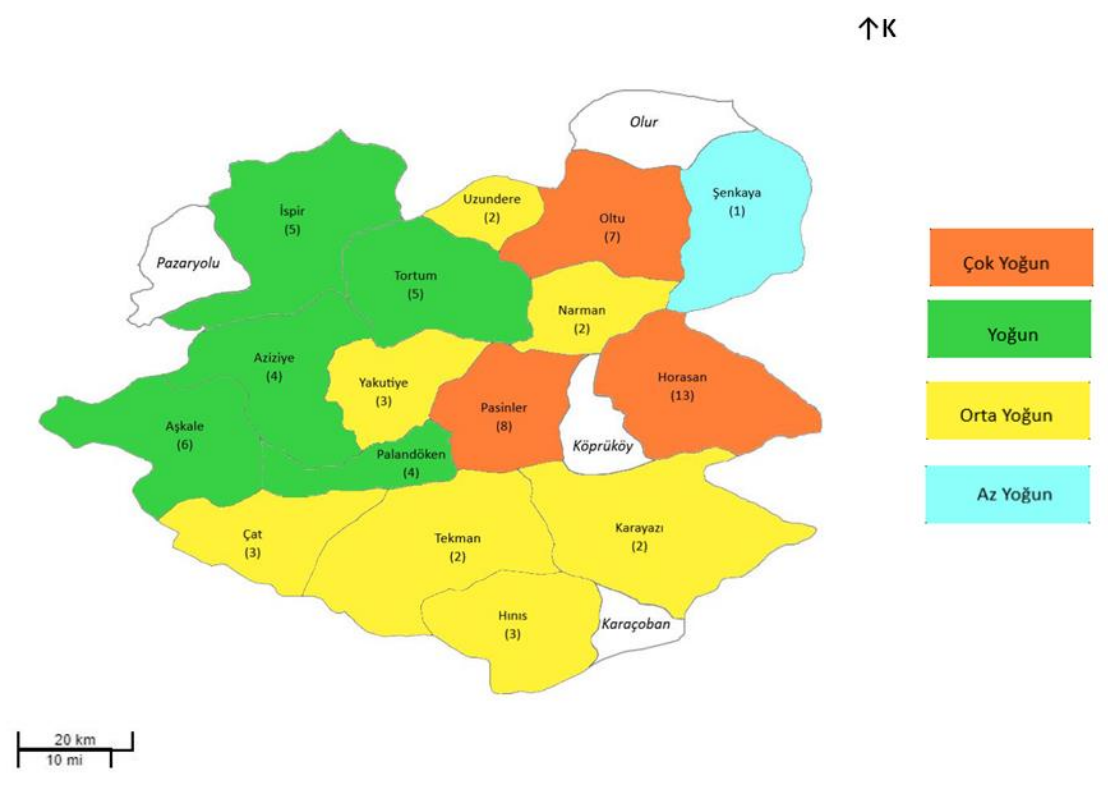

Şekil 11. Erzurum için sel yoğunluk haritası

Şekil 11'de, sel/taşkın olaylarının en fazla Horasan, Oltu ve Pasinler ilçelerinde yoğunlaştığı görülürken, Karaçoban, Köprüköy, Olur ve Pazaryolu ilçelerinde herhangi bir sel/taşkın olayı kaydına ulaşılamamıștır. Oluşturulan veri envanterine göre Oltu ilçesinde çok yoğun olarak görülen sel/taşkın olaylarına karşılık can kaybının az yoğun olduğu ve diğer ilçeler için ise anlamsız bir olay-ölüm sayısı ilişkisi bulunmadığı görülmektedir. Sonuç olarak, çalışma alanında sel olayına bağlı can kayıplarının Horasan'da çok yoğun, Aşkale, Aziziye, Hınıs, Pasinler ve Tortum'da yoğun, Çat, İspir ve Palandöken'de orta yoğun ve son olarak ise Oltu'da az yoğun olduğu belirlenmiştir.

Çalışma alanı içerisinde en genel ifade ile genellikle aşırı, ani yağışlara ve nispeten de çay/nehir taşması ile kar erimelerine bağlı olarak sık sık sel olayı yaşandığını ifade etmek mümkündür. Ayrıca, kar erimesinin çı̆̆ ve sel olaylarını meydana getirebilme potansiyeline sahip olması nedeniyle yeni doğa olaylarının ve belki de afetlerin oluşmasında etkili bir tetikleyici hareket olarak kabul edilmesi gerektiği düşünülmektedir.

\section{SONUÇLAR}

Yapılan bu çalışma ile aktif tektonik yapısı, sahip olduğu iklimsel ve meteorolojik koşullar nedeniyle doğa olayları çeşitliliğinin net bir şekilde gözlendiği Erzurum ilinde 1900-2019 yılları arasında meydana gelen doğa olayları belirlenerek güncel bir veri envanteri oluşturulmuştur. Doğa olaylarının yarattıkları etkiler tespit edilmiş, doğa olaylarının oluşum nedenleri, birbirleri ile özellikle de deprem ile ilişkileri tespit edilerek çalışma alanının doğa olayları profili dolayısı ile de afet potansiyeli belirlenmiştir.

Çalışma alanının depremselliğinin ve deprem tehlikesinin incelendiği zaman dilimi olan 19002019 yılları diğer doğa olayları için de inceleme zaman aralığı olarak kabul edilmiştir. Yapılan çalışmada inceleme yapılan zaman dilimi aynı olmasına rağmen, sağlıklı veriye ulaşımda ve 
envanter oluşturulması esnasında yaşanılan zorluklar nedeniyle istatistiksel ya da rakamsal olarak doğa olaylarını birbiri ile kıyaslamanın doğru olmadığı düşünülmektedir. Bu nedenle ulaşılabilen ve doğruluğu kanıtlanabilen doğa olaylarının her biri kendi içinde çok yoğun, yoğun, orta yoğun ve az yoğun olacak şekilde ilçe bazlı değerlendirilmiş ve ilçe doğa olayları profilleri ortaya çıkartılmıştır. Yapılan bu sınıflama her bir doğa olayı için ulaşılabilen veri sayısına ve oluşturdukları hasara göre kendi içinde gruplandırılarak, değerlendirilmiştir.

Deprem tehlike analizi ile deprem tehlike oranı ve tekrarlanma periyodları belirlenmiştir. Bu kapsamda literatürde yaygın bir şekilde kabul gören yaklaşımlardan Gumbel ve Poisson modelleri tercih edilmiştir. Çalışma alanı için elde edilen sonuçlara göre 1 yılda $M w=5.0$ büyüklüğündeki bir depremin olma ihtimali Gumbel Modeline göre \%26 olarak belirlenirken, Poisson Modeline göre ise \%30'dur. Buna karşıllk 5 yılda Mw=6.6 büyüklüğündeki bir deprem olma ihtimali Gumbel Modeline göre \%12 iken Poisson modeline göre \%6 olarak bulunmuştur. Bu değerler Gumbel Modelinin $M w \geq 6.0$ Poisson Modelinden daha büyük tehlike sonuçları verdiğini göstermektedir. Poisson modeli veri sayısındaki azalmaya bağlı duyarlı sonuçlar verirken Gumbel Dağılımı sadece uç değerler dahilinde hassasiyet sağlamaktadır.

Sel ve çığ oluşumlarının çalışma alanı için deprem dışında afete dönüşme potansiyeli yüksek olan doğa olayları oldukları tespit edilmiştir. Çığ olayının çok yoğun bir şekilde görüldüğü ilçeler İspir ve Palandöken iken sel olayı Horasan, Oltu ve Pasinler'de çok yoğun bir şekilde meydana gelmektedir. Deprem olayları dikkate alınmaksızın yapılan değerlendirme sonucunda Palandöken, Hınıs ve Horasan ilçeleri çığ ve sel oluşumlarına bağlı çok yoğun ölüm oranlarının görüldügü ilçeler olarak ön plana çıkmaktadır.

Oltu ilçesi heyelan, kaya düşmesi, sel ile üç doğa olayının; İspir ilçesi ise çığ ve heyelan ile iki doğa olayının aynı anda çok yoğun bir şekilde gözlendiği ilçeler olarak ön plana çıkmaktadırlar. Pazaryolu ilçesi ise herhangi bir doğa olayı verisine sahip olmayan ilçe olarak dikkat çekmektedir.

Deprem ile çığ, heyelan ve kaya düşmesi arasındaki ilişkilerin net bir şekilde tespit edildiği çalışma alanı içerisinde sel ve heyelan arasında da tetikleyici etkiler belirlenmiştir. Kar erimesine bağlı olarak tespit edilen çı̆̆ ve sel oluşumları ise çalışma alanı için ayrı bir tetikleyici doğa olayı tehlikesi yaratmakttığı gözlenmiştir.

Erzurum için belirli doğa olaylarını kapsayan bu çalışma Türkiye'de iklim değişikliğine bağlı olarak artması beklenen aşırı hava olayları, orman yangınları, fırtınalar vb. doğa olaylarını da içerisine alacak şekilde genişletilebilme potansiyeline sahip olduğu gibi deprem tehlikesini de bölgesel "b" değeri ve "Mmax" değeri belirleme çalışmaları ile desteklemek mümkündür.

\section{KAYNAKLAR}

Akol, B. (2009). Çanakkale ve Çevresinin Deprem Riskinin İncelenmesi, Yüksek Lisans Tezi, Çanakkale Onsekiz Mart Üniversitesi Fen Bilimleri Enstitüsü, Çanakkale, Türkiye.

Akol, B., Bekler, T. (2013). Assessment Of Statistical Earthquake Hazard Parameters For NW Turkey. Natural Hazards, 68, 837-853.

Aksu, B. (2014). Erzurum Şehir Merkezinde Kuzey Güney Doğrultulu Bir Hat Boyunca Yer Alan Yapı Stoğunun, Zemin ve Yapı Periyodu Açısından Değerlendirilmesi, Yüksek Lisans Tezi, Atatürk Üniversitesi Fen Bilimleri Enstitüsü, Erzurum, Türkiye. 
Bozkuş, C., Yılmaz, Ö. (1993). Tercan (Erzincan)-Așkale (Erzurum) Arasının Tektoniği. Türkiye Jeoloji Kurumu Bülteni, 36, 189-201.

Çan, T., Duman, T.Y., Olgun, Ş., Çörekçioğlu, Ş., Gülmez, F.K., Elmacı, H., Hamzaçebi, S., Emre, Ö. (2013). Türkiye Heyelan Veri Tabanı. TMMOB Coğrafi Bilgi Sistemleri Kongresi, 11-13 Kasım, Ankara, Türkiye.

Doğan, A., Yıldırım, C., Nefeslioğlu, H., Emre, Ö. (2004). 25 Mart ve 28 Mart 2004 Aşkale (Erzurum) Depremleri Değerlendirme Raporu. Maden Tetkik ve Arama Genel Müdürlüğü Jeoloji Etütleri Dairesi, Ankara.

Doğu, A.F., Çiçek, İ., Gürgen, G. (1989). 23 Haziran 1988 Çatak Heyelanı (Trabzon-Maçka). Coğrafya Araștırmaları (Atatürk Kültür, Dil ve Tarih Yüksek Kurumu, Coğrafya Bilim ve Uygulama Kolu Yayını), 1(1), 103-107.

Fidan, S. (2019). Türkiye'deki Ölüme Sebep Olan Heyelanların Coğrafi Bilgi Sistemleri (CBS) ile Değerlendirilmesi. Yüksek Lisans Tezi, İstanbul Üniversitesi Sosyal Bilimler Enstitüsü, İstanbul.

Girgin, M. (1996). Așkale Heyelanı (Erzurum). Türk Coğrafya Dergisi, 31, 155-166.

Gökçe, O., Özden, Ş., Demir, A. (2008). Türkiye'de Afetlerin Mekansal ve İstatistiksel Dağılımı Afet Bilgileri Envanteri. Bayındırlık ve İskan Bakanlığı Afet İşleri Genel Müdürlüğü, Afet Etüt ve Hasar Tespit Daire Başkanlığı, Ankara.

Göl, C. (2005). Çığ Olgusu ve Ormancılık. Süleyman Demirel Üniversitesi Orman Fakültesi Dergisi, 1, 49-63.

Gumbel, E.J. (1958). Uç Değer İstatistikleri. New York, USA, Columbia University Press.

Gutenberg, B., Richter, C.F. (1954). Earthquake Magnitude, Intensity, Energy and Acceleration. Bulletin of the Seismological Society of America, 63, 501-516.

Gülal, E., Soycan, M., Dolmaz, N., Erdoğan, S., Kalyoncuoğlu, Y., Yılmaz, İ., Erdoğan, H., Baybura, T., Elitok, Ö., Aykut, O., Ata, E., Akpınar, B., Tiryakioğlu, İ., Gümüş, K., Anadolu, N., Öcalan, T., Telli, A.K., Taktak, F. (2011). Güneybatı Anadolu Bölgesindeki Blok Hareketleri ve Gerilim Alanlarının GNNS Ölçümleri İle Belirlenmesi, TÜBİTAK, $108 Y 298$.

Huvaj, N., Canbay, E., Atıcı, N. (2014). İnşaat Mühendisleri Odası, Erzurum Kayak Pisti İncelemesi ve Tespitler. İnşaat Mühendisleri Odası, Ankara.

Jordanovski, L.R., Todorovska, M.I. (1995). Earthquake Source Parameters For Seismic Hazard Assessment: How To Obtain Them Geologic Data Historic Seismicity And Relative Plate Motions In G. Duma (Ed.). Proc. European Conference Earthquake Engineering, Vienna, Austria, 28 August- 2 September, 1994. Spec. Theme Sess. S01.2: Source Mechanis, Balkema, Rotterdam, 4, 2561-2566.

Kafalı M.A. (2017). "Erzurum İli Uygun Yatırım Alanları Araștırması”. Türkiye Kalkınma Bankası A.Ş., Teknoloji, Araştırma ve İş Geliştirme Daire Başkanlığı, Ankara, Türkiye.

Kiremidjian, A.S. (1982). A Minimum Stress Level Model For Large Earthquakes. Proceeding of the Seventh European Conference on Earthquake Engineering, 20-25 September, Athens, Greece. 
Kopar, İ. (2010). Oluşmuş ve Aktivitesini Sürdüren Karışık Tip Bir Heyelan: ElmalıMadenköprübaşı (İspir-Erzurum) Heyelanı, Sorunlar ve Öneriler. Doğu Coğrafya Dergisi, 15(24), 191-209.

Özşahin, E. (2013). Türkiye'de Yaşanmış (1970-2012) Doğal Afetler Üzerine Bir Değerlendirme. İkinci Türkiye Deprem Mühendisliği ve Sismoloji Konferansı, 25-27 Eylül, Hatay, Türkiye.

Öztürk, K. (2002). Heyelanlar ve Türkiye’ye Etkileri. Gazi Üniversitesi, Gazi Eğitim Fakültesi Dergisi, 22(2) 35-50.

Öztürk, S. (2017). Space-time assessing of the earthquake potential in recent years in the Eastern Anatolia region of Turkey, Earth Sciences Research Journal, 21, 2, 67-75.

Öztürk, S. (2018). Earthquake hazard potential in the Eastern Anatolian Region of Turkey: Seismotectonic b and Dc-values and Precursory Quiescence Z-value, Frontiers of Earth Science, 12, $1,215-236$.

Öztürk, S.M., Çimentepe, E. (2016). Heyelan Riski Olan Yerlerde Mekansal Planların ve Risk Yönetimine Altlık Olan Yerleşime Uygunluk Koşullarının Belirlenmesinde Jeofizik Yöntemlerin Kullanımı, Ulusal Heyelan Sempozyumu Tebliğler, 27-29 Nisan 2016, Ankara.

Poisson, S.D. (1838). Recherches Sur la Probabilite Des Jugements en Matieres Criminelles et Matire Civile. Paris, France, Elibron Classic Series.

Şahin, R., Uysal, H., Çakıcı, F.Z., Çelik, S., Özyazıcıoğlu, M., Kalkan, E. (2016). The Landslide in Erzurum Ski Jumping Complex Part 1: Evaluation of the Landslide and The Incidence". DAAYS'16 Uluslararası Doğal Afet ve Afet Yönetimi Sempozyumu, Karabük.

Şaroğlu, F., Emre, Ö., Boray, A. (1987). Türkiye'nin Diri Fayları ve Depremsellikleri. Maden Tetkik ve Arama Genel Müdürlüğü Jeoloji Etütleri Dairesi Başkanlığı, Ankara.

Şaroğlu, F., Güner, Y. (1981). Doğu Anadolu'nun Jeomorfolojik Gelişimine Etki Eden Ögeler: Jeomorofoloji, Tektonik, Volkanizma İlişkileri. Türkiye Jeoloji Kurumu Bülteni, 24, 39-50.

Tabban, A., Gencoğlu, S. (1975). Deprem ve Parametreleri. Deprem Araştırma Bülteni, 11(7)-83.

URL 1, EM-DAT https://www.emdat.be/ (Son Erişim: 12.12.2020).

URL 2, Cumhuriyet Gazetesi Arşivi (1930-2019) https://www.cumhuriyetarsivi.com.tr (Son Erişim: 1.12.2020).

URL 3, Milliyet Gazetesi Arşivi (1950-2007), http://gazetearsivi.milliyet.com.tr/ (Son Erişim: 8.12.2020).

URL 4, AKOMAS https://akom.ibb.istanbul/akomas/Sayfalar/30/AfetBilgiSistemi-AKOMAS (Son Erişim: 13.01.2021).

URL 5, TABB https://tabb-analiz.afad.gov.tr/ (Son Erişim: 22.01.2021).

URL 6, KRDAE http://www.koeri.boun.edu.tr/sismo/zeqdb/ (Son Erişim: 12.12.2020). 
URL 7, Erzurum Çevre ve Şehircilik İl Müdürlüğü https://erzurum.csb.gov.tr/ (Son Erişim: 11.12.2020)

URL 8, DesInventar https://www.desinventar.net/ (Son Erişim: 11.12.2020).

URL 9, Hürriyet https://www.hurriyet.com.tr/gundem/sel-4-can-aldi-39090343 (Son Erişim: 12.12.2020).

URL 10, NTV http://arsiv.ntv.com.tr/news/260320.asp (Son Erişim: 12.12.2020).

Wiemer, S. (2001). A Software package to analyze seismicity: ZMAP. Seismological Research Letters, 72(2), 373-382.

Yönlü, Ö., Durukan, A., Yalçın, B., Daş, H. (2016). Oltu-Yusufeli (Erzurum-Artvin) Karayolu Heyelanının Jeolojik ve Jeoteknik Değerlendirilmesi. Ulusal Heyelan Sempozyumu Tebliğler, 2729 Nisan, Ankara, Türkiye. 